\title{
ORIGIN AND GEODYNAMIC EVOLUTION OF THE ARCHAEAN CRUST OF EASTERN FINLAND
}

\author{
H. MARTIN; B. AUVRAY; S. BLAIS; R. CAPDEVILA; \\ J. HAMEURT; B. M. JAHN; D. PIQUET; G. QUÉRRÉ, and Ph. VIDAL
}

MARTIN, H.; AUVRAY, B.; BLAIS, S.; CAPDEVILA, R.; HAMEURT, J.; JAHN, B. M.; PIQUET, D.; QUÉRRÉ, G. and VIDAL, Ph., 1984: Origin and geodynamic evolution of the Archean crust of eastern Finland. Bull. Geol. Soc. Finland 56, Part 1-2, 135-160.

The Archaean crust of eastern Finland is composed of three main lithological units:

- Gneissic basement. It was originally composed of tonalites, trondhjemites and granodiorites emplaced at 2.86 G.a. and 2.62 G.a. and subsequently transformed into grey gneisses. The parental magmas originated from the mantle in a two-stage process: (i) formation of a basaltic crust, (ii) melting of this crust transformed into garnet-bearing amphibolite. Field, petrological and geochemical data argue in favour of a subduction-like process rather than an underplate accretion model.

- Greenstone belt (Kuhmo-Suomussalmi). The lower volcanic sequence of this greenstone belt is composed of mafic and ultramafic lavas with komatiitic and tholeiitic affinities and was emplaced at about 2.65 G.a. The uprising of a mantle diapir initiated the breaking of the preexisting sialic crust (grey gneisses) and induced the emplacement of the greenstones in a proto-oceanic rift geodynamic environment.

- Calc-alkaline magmatism. The calc-alkaline magmas were emplaced as volcanic rocks in the greenstone belt 2.5 G.a. ago (Luoma acid volcanics), or as $\mathrm{K}$-feldspar phenocryst granodiorites in the immediate vicinity of the KuhmoSuomussalmi greenstone belt 2.5 G.a. ago (Suomussalmi and Arola augen gneisses). The younger plutons were emplaced as pink leucogranites $2.41 \mathrm{G}$.a. ago. The origin of this magmatism is thought to be correlated to the late tectonic evolution of the Kuhmo-Suomussalmi greenstone belt.

The high density $(\mathrm{d} \sim 3.3)$ lavas of the lower volcanic sequence were emplaced over a low density $(\mathrm{d} \sim 2.7)$ sialic crust. This created an inverse density gradient and generated a gravity instability that initiated the subsidence (sagduction) of the greenstone belt with respect to its basement. This later was carried down in the vicinity of the belt and underwent partial melting, thus generating the calc-alkaline magmas.

It must be pointed out that, in the course of time, petrogenetic processes have changed from ensimatic to ensialic, implying a major reworking of the preexisting crustal materials.

Key words: Archean, greenstone, gneiss, tonalites, crust.

H. Martin; B. Auvray; S. Blais; R. Capdevila; J. Hameurt; B. M. Jahn; D. Piquet; G. Quérré and Ph. Vidal: Centre armoricain d'Etude Structurale des Socles Université de Rennes, Institut de Géologie, 35042 Rennes Cédex, France. 


\section{Introduction}

The increasing number of investigations of Archaean cratons and the progress made in analytical techniques have greatly improved our understanding of the petrogenetic processes occurring during this period of the early history of the Earth. Although, realistic indications about the nature of the sources and the processes of differentiation of the crust are available, the geotectonic environments in which these petrogenetic processes operated are still hypothetical and have given rise to much controversy.

Correlations between the geotectonic environment and the major and trace element composition of magma are very useful for investigations on the late history of the earth (e.g. Condie et al., 1969; Bebien 1973; Pearce and Cann 1973; Glassey 1974; Floyd and Wichester 1975). Unfortunately they must be considered very carefully with regards to archaean time for three:

(1) Lateral and local mantle heterogeneity (e.g. Sun and Nesbitt 1977; Jahn et al. 1980a, 1980b, 1983).

(2) Compositional evolution of the mantle through time (e.g. Glikson 1979; Jahn 1977, Jahn et al. 1980, 1982).

(3) Post crystallization modifications (metamorphism, weathering) (Garcia 1978).

Since there is no miraculous way of establishing a geotectonical environment we have to fix maximum number of petrogenetical and geochemical constraints, which will then be used together with field data to build up models of the geotectonic environment. The model that takes all the constraints into account will be considered as the most realistic one.

Since 1975, our group at Rennes has focussed attention on two areas: The lower Proterozoic granulites of Lapland and the Archaean crust of Finnish Karelia. In the latter area the investigations have been conducted on several types of rocks:
- Greenstone belts (Blais et al. 1977 a, 1977 b; 1978; Bertrand et al. 1978; Jahn et al. 1980 a; Vidal et al. 1980; Auvray et al. 1982; Piquet, 1982).

- Gneissic basement (Vidal et al. 1980; Martin et al. $1983 \mathrm{a}, 1983 \mathrm{~b})$.

- Late granitic intrusions (Vidal et al. 1980; Martin and Quérré 1984; Quérré 1981).

The purpose of this paper is:

a) to attempt a synthesis of all the available data (on Finnish Karelia) and to fix the structural, petrological, geochemical and geochronological constraints;

b) to consider a simple geodynamic process (if one exists) that takes into account the timespace relationship between the different lithological units.

\section{Geological setting and geochronological data}

Archaean terrains are well exposed in Finnish Karelia and extend into Soviet Karelia (Fig. 1). Sederholm (1897) was the first to refer to these terrains as Archaean in age, and he was followed by many authors (Frosterus and Wilkman 1920; Wilkman 1921; Sederholm 1932; Väyrynen 1933, 1954; Matisto 1958; Eskola 1963; Vartiainen 1970; Hyppönen 1973; Bowes (1976). The assumptions of these authors were corroborated by radiometric mesurements (Kouvo 1958; Wetherill et al. 1962; Kouvo and Tilton 1966; Bibikova and Tugarinov 1975; Blais et al. 1977a; Vidal et al. 1980; Patchett et al. 1981; Vaasjoki 1981; Martin et al. 1983a; Martin and Quérré 1984; Peucat et Martin 1984).

Until recently these terrains were divided into two main lithological units (Gaál et al. 1978); the granitoīd association (infrastructure) and the greenstone belts (superstructure).

This scheme appears to be valid but, as proposed by Blais et al. $1977 \mathrm{a}$, the granitoīd association has to be further divided into: (1) 
Fig. 1. Simplified geological map of the Kuhmo-Suomussalmi region showing sampling localities 1) Karelian formation, 2) Archaean greenstone belts, 3) Archaean grey gneiss basement.

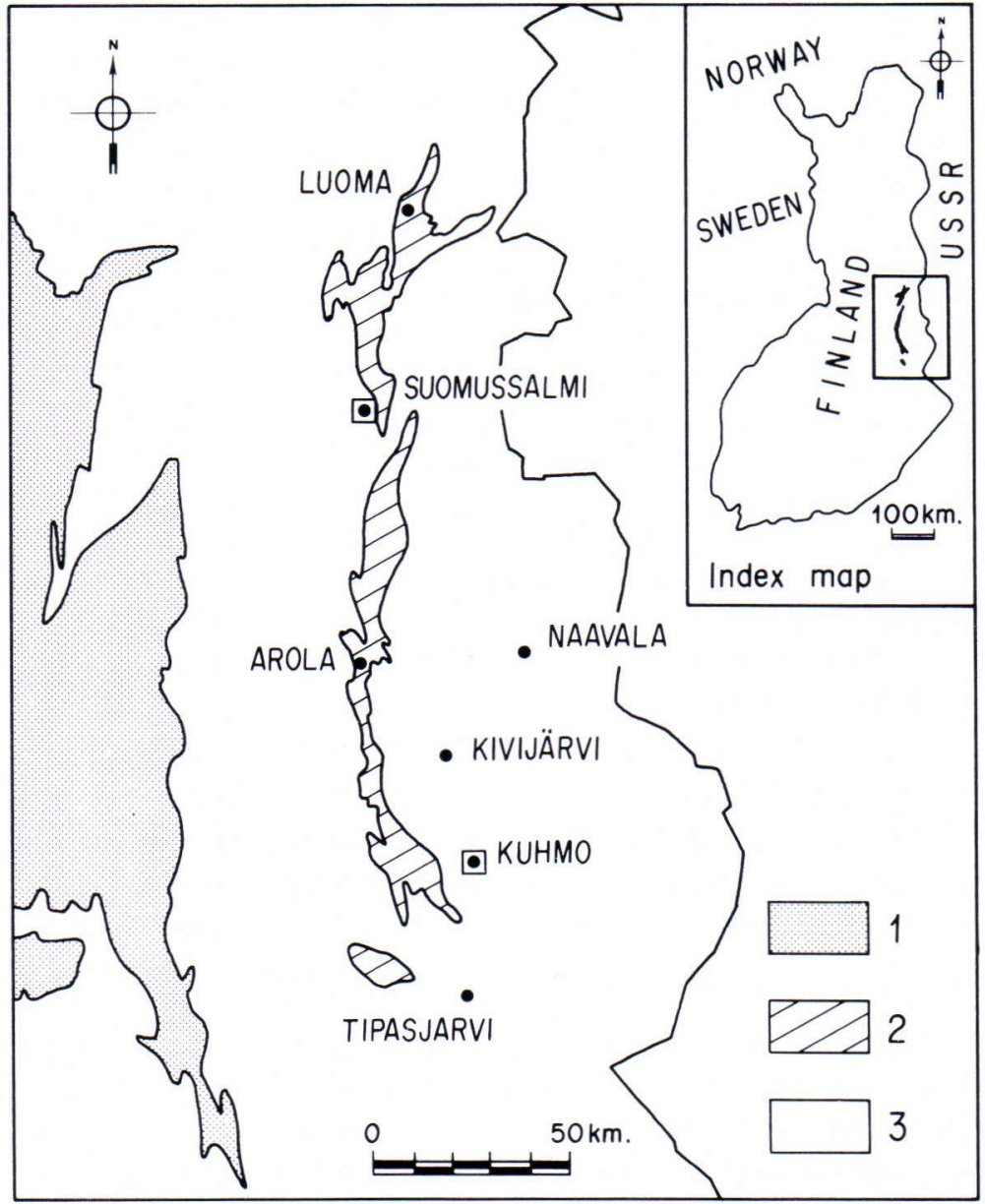

old gneissic basement and (2) late granitic plutons. Thus the subdivision of Finnish Archaean terrains becomes:

a) gneissic basement (grey gneisses)

b) greenstone belts

c) late »granitic» plutons

This threefold classification is characteristic of low-grade, high-level granite-greenstone terrains (Windley and Bridgwater 1971).

\section{The gneissic basement:}

The gneissic basement consists mainly of two generations of orthogneisses (grey gneisses). They are tonalitic trondhjemitic and grano- dioritic (TTG) in composition (Martin et al. 1983 b) and were emplaced in at least two episodes separated by a major tectonic event.

- The Kivijärvi gneisses constitue the oldest generation of grey gneisses. They cover large areas and are medium to fine-grained, substantially migmatised rocks. Their age, determined as $2.86 \pm 0.09$ G.a. by the $\mathrm{Rb}-\mathrm{Sr}$ whole rock isochron method, is supported by $\mathrm{Sm}-\mathrm{Nd}$ isotopic data (Martin et al. 1983 a).

- The Naavala gneisses (younger generation) occur in small bodies, with little or no migmatisation. They are cross cut by basic dykes 
that could be related to the greenstone-belt association. Their age was determined as $2.62 \pm 0.07$ G.a. by various methods $(\mathrm{Rb}-$ $\mathrm{Sr}, \mathrm{Sm}-\mathrm{Nd}$, common lead) (Vidal et al. 1980; Martin et al. 1983 a).

These two generations of grey gneisses have similar mineralogical and chemical compositions. Because of (1) their low initial ${ }^{87} \mathrm{Sr} /{ }^{86} \mathrm{Sr}$ $\left(\mathrm{I}_{\mathrm{Sr}}\right)$ values, (2) their near chondritic $\epsilon_{\mathrm{T}}^{\mathrm{CHUR}}$ values and (3) their strongly fractionated Rare Earth patterns $(\mathrm{La} / \mathrm{Yb})_{\mathrm{N}}=37$ to 103$)$ without europium anomaly it has been proposed that they derived from the mantle according to a twostage model (Martin et al. 1983 b).

(a) formation of a basaltic crust by partial melting of the mantle,

(b) melting of this basaltic crust, transformed into garnet-bearing amphibolite, to generate the TTG magmas. The time elapsing between the two events could not have been more than 100 M.a.

\section{The greenstone belt:}

The more than 200-km-long and less than 20-km-wide Kuhmo-Suomussalmi greenstone belt extends from north to south (Fig. 1). It has been extensively studied in recent years (Mutanen 1976; Blais et al. 1977 a, 1977 b; Bertrand, et al. 1978; Hanski 1979, 1980; Taipale 1979; Tuokko 1979; Jahn et al. 1980; Taipale et al. 1980; Vidal et al. 1980; Auvray et al. 1982; Piquet 1982). The belt can be divided into two cycles of volcanic activity interrupted by a period of sedimentation.

(a) The lower volcanic sequence is by far the most important in volume. It consists mainly of mafic and ultramafic lavas belonging to a komatiitic suite and to a tholeiitic suite (Blais et al. 1977 a, 1977 b; Jahn et al. 1980; Hanski 1979, 1980; Auvray et al. 1982) emplaced as flows, pillow-lavas, breccias, and sills or dykes. Their age was determined as $2.67 \mathrm{G}$.a. by the ${ }^{207} \mathrm{~Pb} /{ }^{206} \mathrm{~Pb}$ method on a non-separated total zircon population (Kouvo and Tilton 1966) and as 2.65 G.a. by the common-lead method (Vidal et al. 1980). Jahn et al. 1980a proposed three different types of source for the mafic and ultramafic magmas of the lower volcanic sequence. All three types have the same initial heavy REE (HREE) but different light REE (LREE) patterns (very depleted, slightly depleted, flat). This LREE depletion has been interpreted as the result of early Archean mantle heterogeneity.

(b) The upper volcanic sequence constitues but a small fraction of the outcrops of the whole belt. It is well exposed north of Suomussalmi and is composed of intermediate to acid rocks (andesite to rhyolite) of calc-alkaline affinity. The age of the sequence has been established as $2.50 \pm 0.10$ G.a. by the Rb-Sr method (Martin et Quérré 1984) and as $2.55 \pm 0.05$ G.a. by the common-lead method. The latter was recalculated by Martin and Quérré (1984) with data from the Luoma acid volcanics published by Kouvo (1965) and by Vidal et al. (1980):

The lower and upper volcanic sequences are separated by a period of deposition of sediments consisting of metapelites metablackshales, metagreywackes, quartzites and some acid metatuffs. These sediments are assumed to derive from the weathering of the grey gneisses of the basement and of the lower volcanic sequence (Blais et al. 1977 a).

\section{The late "granitic» plutons}

The late kinematic to post-kinematic plutons can be subdivided into two main groups:

- Augen gneisses: The protoliths of the augen gneisses were intruded into the greenstone belt as plutonic rocks and subsequently transformed into augen gneisses. They crop out in medium sized to large bodies, mainly in the interface basement-greenstone. They are granodioritic to granitic in composition and contain $\mathrm{K}$-feldspar phenocrysts. Their age was determined by the $\mathrm{Rb}-\mathrm{Sr}$ method as $2.51 \pm 0.11$ G.a. at Suomussalmi (Martin et al. 1983 a) and 2.50 \pm 0.07 G.a. at Arola (Martin and Quérré 1984). These 
authors consider them to be the plutonic equivalents of the acid and intermediate volcanics of the upper volcanic sequence of the greenstone belt. Lobach-Zuckenko et al. (1976) came to the same conclusion regarding the andesites and diorite-porphyries of the greenstone belts of Soviet Karelia. On account of: (1) their REE patterns and (2) their intermediate to high $\mathrm{I}_{\mathrm{Sr}}$ values, the augen gneisses are considered to have formed through partial melting of preexisting grey gneisses from the basement with from time to time assimilation or mixing of mafic components similar to those of the greenstone belt (Martin et al. 1983 b).

- Pink granites: These post-kinematic granites crop out as very small bodies, that intruded both the greenstone belt and the augen gneisses (Quérré 1981). Their age was determined as 2.41 \pm 0.04 G.a. by the $\mathrm{Rb}-\mathrm{Sr}$ method (Martin and Quérré 1984). Their high $I_{S r}$ values and their major and trace element composition indicate that they derived by remelting of the grey gneisses of the basement. In this area they mark the end of Archaean magmatic activity that lasted at least 450 M.a.

The data are summarized in table 1 .

\section{Discussion}

The origin and geotectonic environment of each unit (basement, greenstone belt, late granitic plutons) will be discussed separately. The synthesis and summary of the whole Archaean geodynamic evolution of eastern central Finland will be presented as the conclusion to this paper.

Table 1. Schématic and Synthetic table of the main features of the Archaean rocks of Finnish Karelia.

\begin{tabular}{|c|c|c|c|c|c|c|}
\hline & $\begin{array}{l}\text { Age } \\
\text { in G:a }\end{array}$ & $\begin{array}{l}\text { Infracrustal granite gneiss } \\
\text { association }\end{array}$ & $\begin{array}{l}\text { Surpacrustal greenstone } \\
\text { belt association }\end{array}$ & $\mathrm{I}_{\mathrm{Sr}}$ & $\mathrm{K}_{2} \mathrm{O} / \mathrm{Na}_{2} \mathrm{O}$ & $\begin{array}{l}\text { Geotectonic } \\
\text { environnement }\end{array}$ \\
\hline $\begin{array}{l}\mathrm{K} \\
\mathrm{A} \\
\mathrm{R} \\
\mathrm{E} \\
\mathrm{L} \\
\mathrm{I} \\
\mathrm{A} \\
\mathrm{N}\end{array}$ & 2.0 & \multicolumn{2}{|c|}{ Doleritic Dykes } & & & \\
\hline \multirow{7}{*}{$\begin{array}{l}\text { A } \\
\text { R } \\
\text { C } \\
\text { H } \\
\text { A } \\
\text { E } \\
\text { A } \\
\text { N }\end{array}$} & 2.41 & \multicolumn{2}{|c|}{ Pinkish Granites } & 0.708 & 1.10 & \multirow{3}{*}{$\begin{array}{l}\text { Sagduction } \\
\text { of the } \\
\text { greenstone belt }\end{array}$} \\
\hline & 2.5 & Augen gneisses & $\begin{array}{l}\text { Upper } \\
\text { Acid volcanic sequence }\end{array}$ & to $\begin{array}{l}0.7030 \\
0.7050\end{array}$ & to $\begin{array}{l}0.70 \\
1.00\end{array}$ & \\
\hline & $\begin{array}{l}2.65 \\
2.5\end{array}$ & $\begin{array}{l}\text { Early granodioritic } \\
\text { plutons }\end{array}$ & $\begin{array}{l}\text { Metasediments generated } \\
\text { by the weathering of } \\
\text { the grey gneisses }\end{array}$ & & & \\
\hline & 2.65 & & $\begin{array}{l}\text { Lower mafic and ultramafic } \\
\text { volcanic sequence }\end{array}$ & 0.701 & & $\begin{array}{l}\text { Proto oceanic } \\
\text { rift }\end{array}$ \\
\hline & 2.62 & $\begin{array}{l}\text { Emplacement of Naavala } \\
\text { grey gneisses }\end{array}$ & & 0.7024 & 0.40 & \multirow{2}{*}{$\begin{array}{l}\text { Subduction } \\
\text { zone }\end{array}$} \\
\hline & 2.86 & $\begin{array}{l}\text { Emplacement of Kivijärvi } \\
\text { grey gneisses }\end{array}$ & & 0.7023 & 0.50 & \\
\hline & $>2.86$ & $\begin{array}{l}\text { Basaltic Komatiitite } \\
\text { (inclusion in Kivijärvi } \\
\text { gneisses) }\end{array}$ & & & & $?$ \\
\hline
\end{tabular}




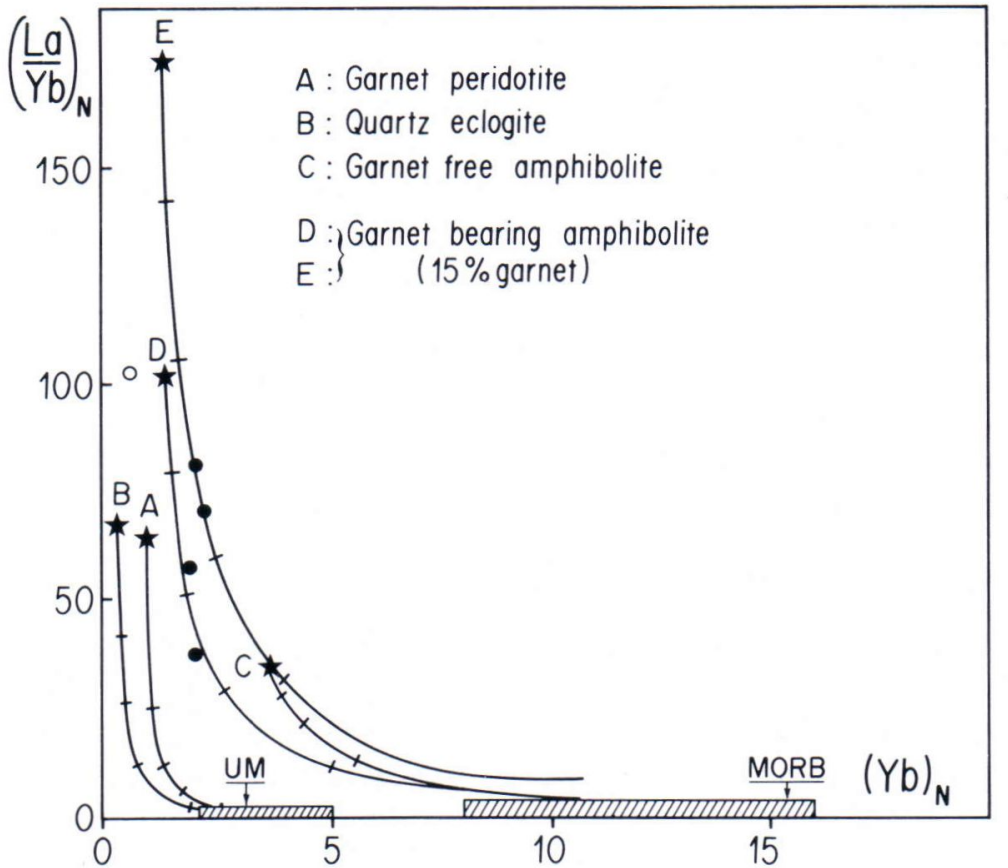

Fig. 2. $(\mathrm{La} / \mathrm{Yb})_{\mathrm{N}}$ vs $(\mathrm{Yb})_{\mathrm{N}}$ diagram for Archaean grey gneiss basement. $\mathrm{Um}=$ upper mantle peridotite field. MORB $=$ Archaean tholeiites and modern MORB field.

The curves represent the trend of liquid composition produced by partial melting of various source materials. The curves were calculated using Shaw's equation (1970) $(C=$ $\mathrm{Co} / \mathrm{D}+\mathrm{F}(1-\mathrm{D})$. Stars represent the limiting values (equivalent to zero per cent of partial melting; short bars perpendicular to the curve correspond to $10 \%, 25 \%, 50 \%$ and $75 \%$ melting. The $(\mathrm{La} / \mathrm{Yb})_{\mathrm{N}}$ and $(\mathrm{Yb})_{\mathrm{N}}$ values for source materials are: curves $\mathrm{A}$ and $\mathrm{B},(\mathrm{La} / \mathrm{Yb})_{\mathrm{N}}=1$; $(\mathrm{Yb})_{\mathrm{N}}=4$; curves $\mathrm{C}$ and $\mathrm{D}$, $(\mathrm{La} / \mathrm{Yb})_{\mathrm{N}}=4 ;(\mathrm{Yb})_{\mathrm{N}}=13 ;$ curve $\mathrm{E}$ $(\mathrm{La} / \mathrm{Yb})_{\mathrm{N}}=10 ;(\mathrm{Yb})_{\mathrm{N}}=10$.
The gneissic basement.

\section{Constraints.}

The grey gneisses were emplaced as plutonic rocks of TTG composition and subsequently transformed into gneisses. Both the Kivijärvi and the Naavala types of grey gneiss have low $\mathrm{I}_{\mathrm{Sr}}$ values $(0.7023$ and 0.7024 , respectively). Within the limits of analytical uncertainty, these low $\mathrm{I}_{\mathrm{Sr}}$ values are close to the terrestrial mantle Sr evolution path (Fig. 7). Their mantle-like isotopic composition is corroborated by: (1) the nearly chondritic $\mathrm{Nd} \epsilon_{\mathrm{T}}^{\mathrm{CHUR}}$ values ( -0.2 to + 0.4) (Martin et al. 1983 a) and (2) the $\mu$ values calculated as 8.05 in a two-stage lead evolution model (Vidal et al. 1980). These isotopic data indicate that the TTG magmas were generated more or less directly from the mantle and preclude the derivation of the grey gneiss protolith from much older continental materials.

The REE patterns of the grey gneisses are strongly fractionated $(\mathrm{La} / \mathrm{Yb}=37$ to 103$)$ and without europium anomaly. Figure 2 clearly shows that, with respect to REE patterns, the TTG magmas cannot be derived directly from an uncontaminated mantle: they are better explained by a two-stage petrogenetic model (Martin et al. 1983 b): (1) formation of a basaltic crust by partial melting of the mantle and (2) genesis of the TTG magmas by partial melting of the basaltic crust transformed into garnetbearing amphibolite.

The TTG magmas may also have formed through direct melting of a contaminated mantle. This later is contaminated by a fluid enriched in light REE (LREE), thereby causing its solidus temperature to decrease. Partial melting of a hydrated, LREE-enriched mantle could have generated calc-akaline magmas of TTG composition. Such a fluid enrichment of the mantle in present-day subduction zones is attributed to dehydration of the subducted oceanic crust (e.g. Poldervaart 1955; Yoder 1969; O'Hara and Yoder 1963; Wyllie 1979; Gills 1981).

These two assumptions seem to be equally 
valid. Nevertheless, all $\mathrm{I}_{\mathrm{Sr}}$ values are slightly higher than those for the mantle (Fig. 6). This deviation is apparent not only in Finnish gneisses but also in all Archaean grey gneisses the world over (e.g. Moorbath et al. 1972, 1977; Jahn and Nyquist 1976; Hart and Brooks 1977; Cooper et al. 1978; Glikson 1979; Jahn et al. 1980). So, it can be pointed out that: (1) a direct mantle origin (contaminated or not) should have preserved true mantle $\mathrm{I}_{\mathrm{Sr}}$ values (2) a mantle heterogeneity could only explain local $\mathrm{I}_{\mathrm{Sr}}$ anomalie and (3) a two-stage model in which the first stage crustal residence time is less than 100 M.a. could explain the invariably slightly high $\mathrm{I}_{\mathrm{Sr}}$.

This is why the two-stage model is preferred to the contaminated mantle melting process (see Maaløe and Petersen 1981).

- The concave form of the HREE end and theoretical geochemical calculations imply the existence of hornblende and garnet in the residue of the melt (Martin et al. $1983 \mathrm{~b}$ ). This indicates that the garnet was stable under the thermodynamic conditions of melting of the basic crust and consequently implies a low geothermic gradient. Indeed, with a high geothermic gradient the liquidus of hydrous tholeiite is reached before garnet attains stability (Fig. 3), (Wyllie 1971; Stern et al. 1975). According to experimental data, the geothermic gradient must range between $25^{\circ} \mathrm{C} \mathrm{km}^{-1}$ and $35^{\circ} \mathrm{C}$ $\mathrm{km}^{-1}$ (Condie 1980, 1981). A higher geothermic gradient should preclude the stability of garnet during the melting of a tholeiite. Wells (1979) corroborates these conclusions. On the basis of field and petrological data, he proposes an Archaean geothermic gradient ranging from $15^{\circ} \mathrm{C} \mathrm{km}^{-1}$ to $40^{\circ} \mathrm{C} \mathrm{km}^{-1}$ with an average value close to $25^{\circ} \mathrm{C} \mathrm{km}^{-1}$ in Greenland. Thus the geodynamic model that will be proposed must take into account gradients close to $30^{\circ} \mathrm{C}$ $\mathrm{km}^{-1}$.

- In Karelia, as in all Archaean granitegreenstone, terrains the TTG cover very large areas. They have an average thickness of $45 \mathrm{~km}$

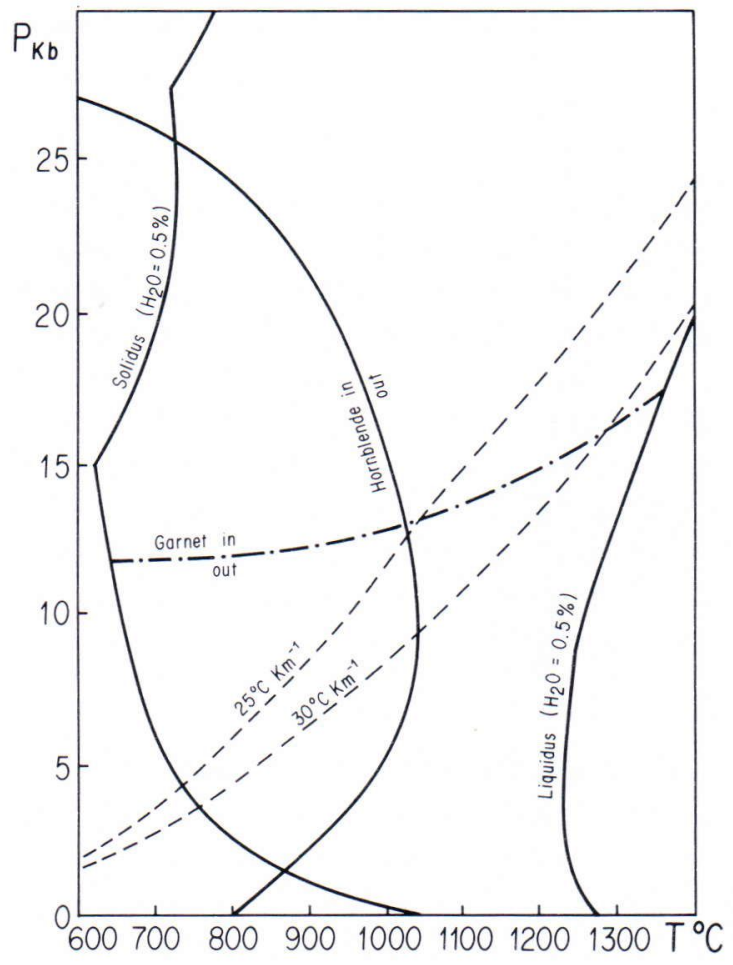

Fig. 3. Melting relations of hydrous tholeiites $\left(0.5 \% \mathrm{H}_{2} \mathrm{O}\right)$ (after Wyllie, 1971). The curve for the breakdown of hornblende is after Lambert and Wyllie (1980), and the garnet stability field after Stern et al. (1975). Dotted lines are geotherms.

(Bungum et al. 1980; Calganile 1982) and represent enormous volumes of magmas. The genesis of these magmas necessitated partial melting of large volumes of mafic crust. The degree of partial melting necessary to produce TTG magmas is considered as $\leqslant 25 \%$ (Arth 1979; Barker 1979; Condie 1980; Hanson 1980; Martin et al. 1983 b). Thus the volume of ultramafic residue should be three times the volume of TTG magmas. Residues or remnants of basaltic crust of such proportions are unknown in eastern Finland (except for enclaves some centimeters to several decimeters thick). The geodynamic model should explain not only the melting of the mafic crust, but also the complete disappearance of the residue and the absence of mafic remnants. 
- In this part of Finland, the oldest rock unit recognized to date is the Kivijärvi grey gneiss. (The 3.1 G.a. old Koitelainen gneisses, crop out in Lapland more than $450 \mathrm{~km}$ to the north, Kröner et al. 1981). Thus the oldest magmas may have formed in an "oceanic» rather than in a »continental» environment. This assumption holds for the first stages of continental growth $(\sim 2.9$ G.a. in this area), but clearly the subsequent emplacement of TTG (Naavala type of grey gneiss and perhaps the later Kivijärvi gneiss protoliths) occured in a continental environment; when the oldest Kivijärvi TTG were already emplaced and constituted the early continental crust in this area.

\section{Discussion and model.}

There are two main sets of hypothesis to explain how all or part of a basic crust reaches the thermodynamic conditions of partial melting.

- Plate tectonic-like mechanisms operated in Archaean time and the basaltic crust was molten and disappeared in subduction zones (Talbot 1973; Rutland 1973; Tarney et al. 1976; Windley 1976, 1977; Windley and Smith 1976; Burke and Kidd 1978; Condie 1980 etc...)

- Plate tectonic-like mechanisms did not operate in Archaean time and only the basis of a thick basaltic crust underwant partial melting (e.g. Green and Ringwood 1968; Glikson 1972; Barker and Arth 1976; Barker 1979). The crust could have thickened locally in a down sagging basin through some sag-duction process (Glikson 1971; Gorman et al. 1978).

If plate tectonic-like mechanisms did not operate in Archaean time, the mafic crust would have been very thick. Fig. 3 shows that, with an average geothermic gradient close to $30^{\circ} \mathrm{C}$ $\mathrm{km}^{-1}$, the solidus of a hydrous tholeiite is reached at a depth of more than $40 \mathrm{~km}$. This value exceeds by 10 to $20 \mathrm{~km}$ that given by Wells (1979) for the Archaean crust in Greenland and is six times higher than the thickness of present oceanic crust $(7 \mathrm{~km})$. This assumption implies a crustal thicknening of 24 to $35 \mathrm{~km}$ during less than 100 M.a. Thus the vertical accretion velocity ranged between $2.510^{-4}$ and $3.510^{-4} \mathrm{my}^{-1}$.

In the case of a thick mafic crust, only the five deepest kilometers (12\% of the 40-km-thick crust) should reach the thermodynamic conditions of partial melting. The TTG magmas cannot be produced by more than $25 \%$ of partial melting of the mafic crust; thus only $3 \%(25 \%$ of $12 \%$ ) of the whole mafic crust will disappear by partial melting. In others words, the mafic and ultramafic residue and the mafic remnants should continuously represent $97 \%$ of the initial mafic crust and more than 30 times the volume of the TTG magmas produced.

This assumption obviously does not take into account the absence of mafic and ultramafic remnants from Finnish Archaean terrains. Yet the addition of low-density TTG rocks to the mafic crust will resist down motion by reducing the global density of the crust. The process should come to an end quickly before large volumes of TTG rocks are formed.

The assumption of local thickening of the mafic crust by a sagduction process (Gorman et al. 1978) is not suitable. Sag-duction is induced by an inverse density gradient. It implies high density rocks overlying low density ones, and hence mafic and ultramafic rocks overlying felsic ones. The absence of continental crust older than 2.86 G.a. precludes the existence of an inverse density gradient, and thus argues against crustal thickening by a sag-duction process in this part of Finland.

If plate tectonic-like processes operated in Archaean time, TTG magmas should occur in subduction zones. Nowaday calc-alkaline magmatism is produced in this geotectonic environment either (1) by partial melting of the oceanic crust and possibly of its sediments, or (2) by partial melting of a mantle contaminated with water coming from the dehydration of the underlaying subducted oceanic crust. Whatever the actual process is, it implies the existence and sinking into the mantle of an oceanic crust. In eastern Finland, the geochemical characteristics 
of the TTG magmas implies the melting of a mafic crust rather than of a contaminated mantle (see discussion of constraints).

It is tempting to draw an analogy between the geotectonic environment of Archaean TTG magma genesis and subduction zones, because it would explain both the partial melting and the complete disappearance of the mafic crust. Moreover, partial melting does affect not only the base but the whole mafic crust. After removal of the TTG melt, the density of the residue increases, changing from $\mathrm{d}=3.3$ (garnetbearing amphibolite) to $\mathrm{d}=3.5$ after extraction of $25 \%$ of a low density melt $(d=2.6)$. Residue of such density will be recycled and reincorporated into the upper mantle.

Thus, the lack of mafic relicts is explained and large volumes of TTG magmas can be produced. Yet this process does not necessitate mafic crust of a normal thickness.

The grey gneisses of eastern central Finland and Soviet Karelia crop out over more than 0.25 $\times 10^{6} \mathrm{~km}^{2}$. The average crustal thickness of this part of the Baltic shield is $45 \mathrm{~km}$ (Bungum et al. 1980; Galganile 1982). The volume of grey gneisses can therefore be estimated as $11 \times 10^{6}$ $\mathrm{km}^{3}$. A volume of grey gneisses of this proportion implies the partial melting $(25 \%)$ of $44 \times$ $10^{6} \mathrm{~km}^{3}$ of the mafic crust. With an average thickness of $7 \mathrm{~km}$, the mafic crust should have had a surface of $\sim 6 \times 10^{6} \mathrm{~km}^{2}$. Isotopic data indicate that partial melting of the mafic crust occured less than 100 M.a. after its emplacement (Martin et al. 1983 a).

Fig. 4 shows the relationship between the slab motion rate and its shape and thickness. Calculations were performed assuming (1) that there was only one slab, and (2) that the slab had reached its maximum size (the slab was completely generated before subduction began). A logical consequence of these assumptions is that the calculated values are maxima, and that the true values must be several times lower. The diagram shows clearly that for a trench $10^{3} \mathrm{~km}$ long (more than from Savukoski to Ilomantsi) the motion rate ranges between $0.06 \mathrm{~m}$. year ${ }^{-1}$ and $0.20 \mathrm{~m}$. year ${ }^{-1}$. These values are in good agreement with the present subduction rates (e.g. Le Pichon 1968; Oxburgh 1974; Forsythe and Uyeda 1975; Windley 1977), but lower than the velocity of $\operatorname{lm}$ a year proposed by MacKenzie and Weiss (1975) for an Archaean crust with a geotherm gradient of $60^{\circ} \mathrm{C} \mathrm{km}^{-1}$.

Note also that the calculated size of the plate (which is a maximum) is consistent with the assumptions of several authors (MacKenzie and Weiss 1975; Burke et al. 1976; Condie 1980). They consider that, in Archaean times, heat generation was greater than it is today. Because there is no heat dissipating process peculiar to the Archaean, they infer that the ridge length and spreading rates were greater than today, and consequently that the plate size was smaller.

The lack of linear structures in the Archaean grey gneisses of Finnish Karelia seems to argue against a plate tectonic model; one would expect cordilleran-like structures in subduction zones. One explanation may be that there were numerous small plates and not just a few big ones as nowadays. The accretion of continental crust should have happened not only by the addition of magma in subduction zones, but also by aggregation of small sialic crustal fragments (MacKenzie and Weiss 1975; Windley 1977; Condie 1980, 1981). Thus large-scale linear structures probably did not exist and small linear structures, even if they did exist, would have been obliterated by numerous collisions. This assumption if based upon at least two items of fields data: (1) The earlier phase of deformation, which exists only in the basement old gneisses, is responsible for the dominant rock fabric and is associated with intrafolial isoclinal folds. This foliation is parallel to the lithological layering (Bowes 1976; Blais et al. 1977 a; Bertrand et al. 1978; Gaál et al. 1978). (2) This early deformation is associated with a migmatitic event. The 2.86 G.a.-old Kivijärvi grey gneisses are migmatised but the 2.62 G.a.old Naavala one are not. Both the Kivijärvi and 


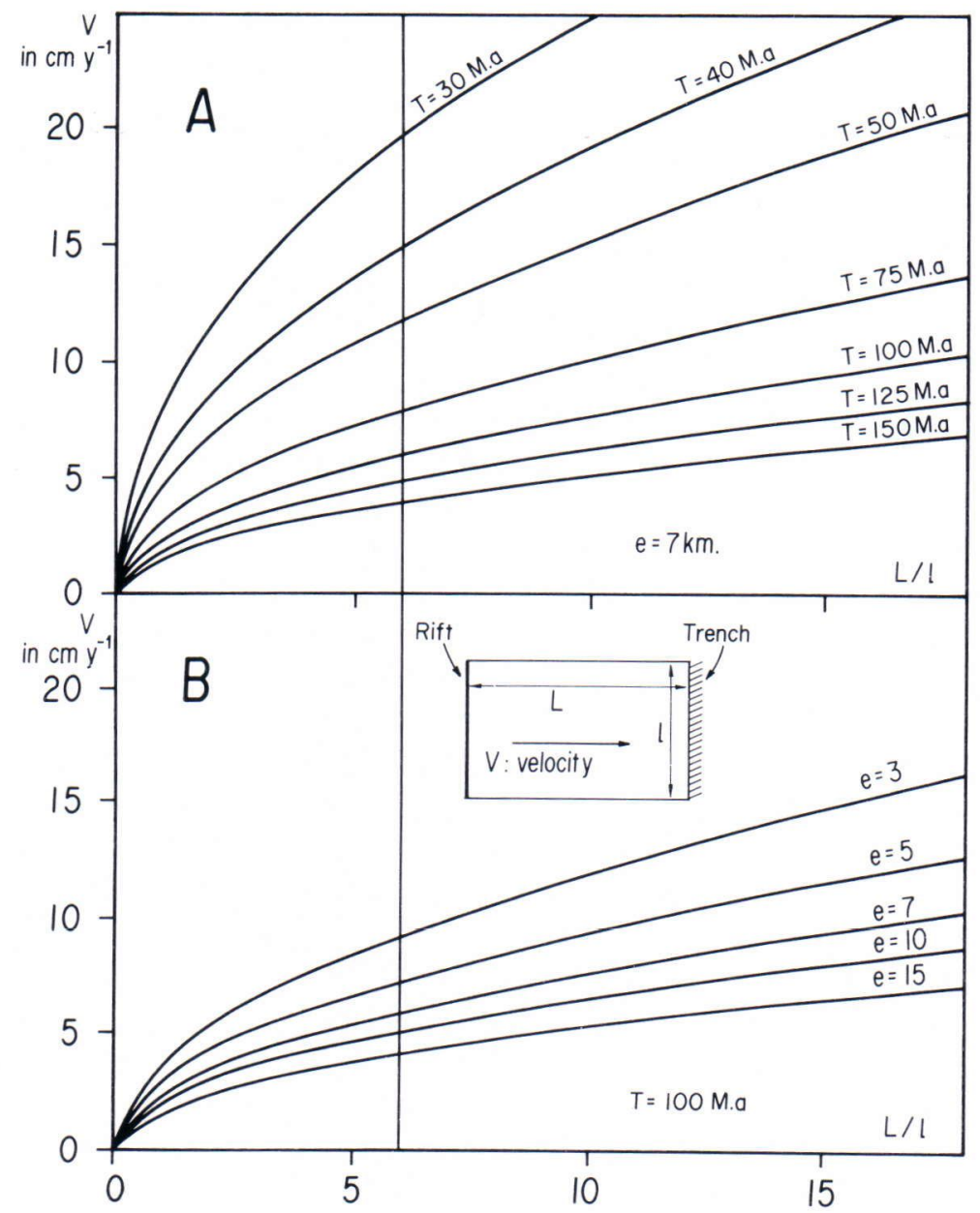

Fig. 4. Diagram showing the relations between the shape of the slab (L $=$ distance from ridge to trench, $1=$ trench length) and rate of motion. The calculations were performed assuming that the whole TTG of Finnish and Soviet Karelia $\left(10 \times 10^{6}\right.$ $\mathrm{km}^{3}$ ) were generated by $25 \%$ partial melting of a mafic crust in subduction zones.

Diagram A was drawn assuming that it needs $T$ years for an element of the slab to move from the rift to the trench. Note that the $\mathrm{I}_{\mathrm{Sr}}$ and $\mathrm{Nd}$ $\epsilon_{\mathrm{T}}^{\mathrm{CHUR}}$ indicate that $\mathrm{T}$ was less than 100 M.a.

Diagram B was built assuming different mafic slab thicknesses with $T$ $=100$ M.a. the Naavala gneisses were emplaced in the same area (Naavala gneisses are intrusive to Kivijärvi ones), and have indentical mineralogical and chemical composition. The same thermodynamic conditions should have induced migmatisation in rocks of similar composition. The Naavala gneisses are not migmatised, so it can be concluded that anatexis occurred before the emplacement of the Naavala TTG: after 2.86 G.a. and before 2.62 G.a. (Peucat and Martin 1984).

The strong foliation parallel to the lithological layering associated with intrafolial isoclinal folds should be the result to tangential tectonic movements caused by the collision and thrusting of two crustal fragments. This collision induced crustal thickening and triggered the metamorphism and anatexis of the TTG. This »classical» process could explain the early structures of the Kivijärvi grey gneisses.

A consequence of this process of crustal accretion is the apparition of super continents on the Early Proterozoīc (Piper 1976).

Many investigators agree with plate tectoniclike processes in Archaean time. A consequence of the progressive cooling of the Earth in the early stages of its history is the crystallisation of a thin lithosphere. The difference in temperature 
between surface and depth induced mantle convention and correlated plate motion in Archaean time (e.g. Elder 1972; Rutland 1973; Talbot 1973; MacKenzie and Weiss 1975; Sutton 1975; Tarney et al. 1976; Windley 1976, 1977; Windley and Smith 1976; Burke and Kidd 1978; Condie 1980, 1981).

The TTG magmas were produced directly from a »basaltic» crust. This assumes that the initial crust was »basaltic» in composition, and so the question still remains: what is the origin of the »basaltic» crust? This crust could have been produced if rift systems generated by mantle plume activity. The rising of a plume initiated the genesis of »basaltic» liquids by partial melting of the mantle. The newly generated magmas were then added to the mafic crust (Condie 1975, 1980; Condie and Hunter 1976).

\section{The greenstone belt.}

\section{Constraints.}

The lower volcanic sequence of the KuhmoSuomussalmi greenstone belt was emplaced in a continental-like geotectonic environment. The field data clearly indicate the anteriority of the basement grey gneisses: the basement underwent at least one tectonometamorphic event before the deposition of the greenstone belt (Blais et al. 1977 a; Bertrand et al. 1978) and basic dykes intruding the Naavala grey gneisses could be related to the greenstone belt (Martin and Quérré 1984). These results are corroborated by radiometric data (Vidal et al. 1980; Martin et al. 1983 a). The basement is not only older than the greenstone belt, but is was also geographically in the immediate vicinity of the site of its despotion. This assertion is supported by the composition of the detrital metasediments interbedded with or overlaying the lower volcanic sequence. These sediments contains detrital minerals, e.g. microcline, from the basement (Blais et al. 1977 a; Bertrand et al. 1978; Taipale et al. 1980). Laajoki and Lavikainen (1977) pointed out that the REE patterns of the sediments of the belt indicate that they derived from a granodioritic to granitic source. Thus the sedimentation in the greenstone belt environment may have been provided by the erosion and alteration of the surrounding grey gneisses of the basement. This also implies that the greenstone was emplaced in a basin in which the surrounding grey gneisses had a prominent position.

An important orogenic event must have taken place in this area after the TTG intrusion and before the emplacement of the greenstone belt. The TTG should have moved up from their cooling place into the crust and towards the surface, where they were altered and weathered. This event could explain the transformation of the TTG into grey gneisses and could be related to the type of crustal accretion discussed at the end of the previous chapter.

The lower volcanic sequence of the KuhmoSuomussalmi greenstone belt was emplaced at the bottom of a sea. This is clearly indicated by the existence of pillow lavas, mainly in the komatiitic suite, and by the petrological and chemical nature of the sediments associated with the mafic and ultramafic lavas. The sediments are mainly schists and greywackes with minor amounts of quartzite, conglomerate and banded iron formation (Blais et al. 1977 a; Tuokko 1979; Taipale et al. 1980; Auvray et al. 1982). Nevertheless, the lack of abundant vacuoles in the pillow lavas, the existence of breccias and scorias (Auvray et al. 1982) and the deposition of banded iron formation indicate deposition of the greenstone materials under shallow water conditions (Goodwin 1973).

The Kuhmo-Suomussalmi greenstone belt has a linear structure: it is roughly elongated from north to south, and is over $200 \mathrm{~km}$ long with a width of less than $20 \mathrm{~km}$. Geometrically the lower sequence seems to form a syncline with the grey gneisses of the basement (Fig. 5). (Blais et al. 1977 a). This structure is corroborated by the new maps of the area (Hanski 1979; Taipale 1979; Tuokko 1979). A detailed study of the basement shows that its nature, its 


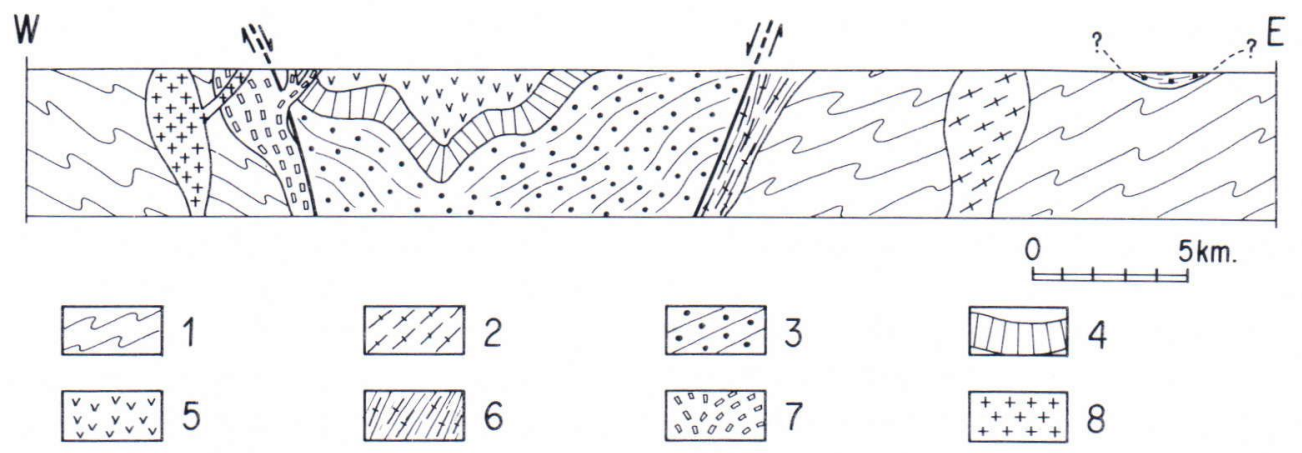

Fig. 5. Schematic cross-section through the Kuhmo-Suomussalmi Archaean rocks.

$\begin{aligned} \text { Basement } & : 1-2.86 \text { G.a. Kivijärvi grey gneisses. } \\ \text { Greenstone belt } & : 2-2.62 \text { G.a. Naavala grey gneisses. } \\ & : 3-2.65 \text { G.a. mafic and ultramafic lower volcanic sequence. } \\ & : 4- \\ \text { Calc-alkaline plutons } & : 6 \text { post } 2.65 \text { ante } 2.5 \text { G.a. Calc-alkali granodiorite plutons. } \\ & : 7-2.50 \text { G.a. augen gneisses. } \\ & : 8-2.41 \text { G.a. pink leucogranite. }\end{aligned}$

mineralogical and chemical composition and its tectonic history are exactly the same on both sides of the belt. This fact together with the structure of the belt implies that the greenstone belt developed into a single sialic segment rather than that greenstones constitute the limit between two different crustal fragments.

The mafic and ultramafic lavas of the lower volcanic sequence of the Kuhmo-Suomussal$\mathrm{mi}$ greenstone belt are komatiites and low- $\mathrm{K}$ tholeiites. Jahn et al. (1980 a) propose three different types of source material for all the mafic and ultramafic lavas of this area. All three types had the same initial HREE (2X chondrites) but different LREE (very depleted to $2 \mathrm{X}$ chondrites, flat). They consider that the depths of partial melting and segregation of the magmas were different: the uprising peridotitic diapir sampled different levels of the heterogeneous mantle. The authors assume that the mantle heterogeneity was very probably the consequence of contemporaneous to previous continental crust-forming events (this indirectly corroborates, if necessary, the early ages of the grey gneisses). However, the degrees of partial melting of the pyrolite should be very high ( $\mathrm{F}$ 50 \%) (Green 1975; Arndt 1977; Blais et al. 1977 b; Naldrett and Turner 1977; O’Nions and Pankhurst 1978; Nisbet et al. 1979; Jahn et al. 1980 a; Auvray et al. 1982; Nisbet 1982). These partial melting conditions are reached at great depth and/or with high geothermal gradients (Green 1975; Sun and Nesbitt 1978; Jahn et al. 1980; Nisbet 1982). The anormaly high geothermal gradient is induced by the uprising of a mantle diapir (from a depth of more than 400 $\mathrm{km})$. Because of the limited size of the mantle diapir, the high geothermal gradient should have been restricted to a strong but local thermal anomaly.

Discussion and model.

The lower volcanic sequence of the KuhmoSuomussalmi greenstone belt (Blais et al. 1977 a; Auvray et al. 1982, and with some restrictions Gaál et al. 1978) has been considered as paleo-oceanic crust because of:

- the presence of pillow lavas of submarine origin, 
- the absence of vacuoles in the pillow lavas, and the nature of the sediments (e.g. greywackes, black-shales, banded iron formation) indicating that the greenstones were emplaced under shallow water conditions rather than at the bottom of a deep ocean;

- the chemical composition of the mafic and ultramafic lavas (komatiites and low-K tholeiites), and the magmatic associations (peridotites, gabbros, dolerites, massive and pillow lavas) corroborate their oceanic origin. In the light of field and chemical data, Blais et al. (1977 a) consider the Kuhmo-Suomussalmi greenstone belt to be what they call an »ophiolitoīde».

These conclusions are consistent with those of several authors regarding various greenstone belts. By their nature, composition and structure the mafic and ultramafic lavas of the Archaean greenstone belts are held to be equivalent to oceanic crust (e.g. Glikson 1970, 1971; Goodwin and Ridler 1970; White et al. 1971; Windley 1973, 1977; Engel et al. $1974 \mathrm{Jahn}$ et al. 1974; Burke et al. 1975; Condie 1975, 1980; Tarney 1976).

The present area covered by the KuhmoSuomussalmi greenstone belt is negligible compared with the vast granite-gneiss terrains. So the question is: does the greenstone belt correspond to the relict of a large ocean? If the answer is positive, then the belt represents a suture between two continental blocks and the bulk of the oceanic crust should have disappeared. Nowadays, the oceanic crust disappears by recycling, through subduction zones, into the mantle. In subduction zones, tangential tectonic structures should be expected both in the greenstone belt and in the basement. Structures like this are very well exposed, in the lower Proterozoic terrains of Lapland where the Tana River belt (linearly shaped relict of oceanic crust), the granulitic belt and the surrounding basement have undergone strong tangential tectonic movements (Barbey et al. 1980; Barbey 1982). In contrast, in Karelia, the main tectonic structures of the belt are vertical or subvertical, and the basement-greenstone belt interface is affected by vertical shear zones (Blais et al. 1977 a; Bertrand et al. 1978; Taipale et al. 1980).

With regard to tectonic therefore, the field data are inconsistent with the subduction hypothesis.

- Subduction of the oceanic crust generates calc-alkaline magmatism. In Finnish Karelia, calc-alkaline plutonic and volcanic rocks are well known (Blais et al. 1977 a; Taipale et al. 1980; Jahn et al. 1980; Vidal et al. 1980; Auvray et al. 1982; Martin et al. 1983 a, 1983 b; Martin and Quérré 1984). All these magmas were emplaced after the deposition of the lower volcanic sequence of the greenstone belt. They intrude or overlie the lower volcanic sequence and the basement in the immediate civinity of the belt. Nevertheless the relatively small volume of calc-alkaline rocks contradictes the hypothesis of a large ocean; partial melting of large volumes of oceanic crust would have generated greater amounts of calc-alkaline magmas.

The distribution of calc-alkaline magmatic rocks in the trench is strongly assymmetrical: they have been emplaced on one side of the trench, over the subducted slab. In Finnish Karelia, calc-alkaline magmatic rocks are located in the immediate vicinity of the greenstone belt, but their distribution is exactly the same on both sides, when a large dissymmetry should be excepted.

The greater the distance from the trench the greater the variation in the composition of the calc-alkaline is (e.g. Kuno 1959, 1960; Sugimura 1960, 1968; Dickinson 1968; Miyashiro 1972; Gill 1981). This type of magmatic zonation is unknown in Karelia.

The Kuhmo-Suomussalmi greenstone belt has a synform structure within the basement (Fig. 5). The grey gneisses on either side of the belt have exactly the same nature, mineralogical and chemical composition, and tectono-meta- 
morphic history. This indicates that they have belonged to the same sialic block since long before the emplacement of the greenstone belt. Hence these is do doubt that the Kuhmo-Suomussalmi greenstone belt was emplaced in a single sialic block rather than as a large ocean between two different continental blocks.

Evidence abounds to preclude the hypothesis of a large ocean and to favour the minor development of oceanic crust in an ensialic environment. On the basis of field data Blais et al. (1977 a) proposed a protorift geotectonic environment: the process of rifting began in an ensialic environment, but stopped before the development of a true large ocean.

The structure of the Kuhmo-Suomussalmi greenstone belt implies a simple classical scheme, i.e. the belt is only one episode of volcanic activity it evolves from komatiites and low-K tholeiites at the bottom to intermediate and acid volcanics at the top (see Blais et al. 1977 a; Martin and Quérré 1984).

The finnish greenstone belts are therefore different from other greenstone belts elsewhere in the world, where there are several cycles of volcanic activity (e.g. in Abitibi, Goodwin 1979; Capdevila 1982, in Swaziland Anhaeusser et al. 1969, or in the Superior Province, Hubregtse 1976; Ayres 1977). The elementary nature of the belt supportes the protorift hypothesis.

The nature of the sediments associated with and overlying the lower volcanic sequence clearly indicates that they originated, at least partly, through erosion and alteration of the surrounding granodioritic basement (Laajoki and Lavikainen 1977; Blais et al. 1977 a; Bertrand et al. 1978; Taipale et al. 1980). Thus, the greenstone belt was emplaced in the immediate vicinity of the continental crust (the basement).

The structure of the greenstone belt is a large syncline with faulted margins and vertical folds (Fig. 5). Estimates of its present-day thickness range from 5000 to $6000 \mathrm{~m}$ (Blais et al. 1978; Taipale et al. 1980); nowhere it is wider than 20 $\mathrm{km}$ (sometimes less than $2 \mathrm{~km}$ ). The linear shape of the belt cannot therefore be entirely primary. This is corroborated by several small (from decimeters to kilometers in size) isolated outcrops of greenstone materials scattered over the gneissic basement on both sides of the belt itself (see Gaál et al. 1976; Rybakov and Lobach-Zhuckenko 1981 a). This is evidence of (1) a larger, original extent of the belt and (2) the deposition of the greenstone belt over a preexisting sialic crust. These structures can be compared with the structures of the Archaean greenstone belts of the Canadian Shield. Goodwin and Ridler (1970) have defined large volcanic complexes in the Abitibi belt, whose original diame _. was from 100 to $175 \mathrm{~km}$. Each complex is composed of many volcanic centers.

A number of other volcanic complexe have been described by Rybakov (1980) and Rybakov et al. (1979, 1981 a et b), from Soviet Karelia. The greenstone belts there (e.g. Kenozero, Kozhozero, Taksja, Hautavaara, Kostamuskoa, Jalonvaara) display many similarities with the Kuhmo-Suomussalmi belt.

As suggested by Gorman et al. (1978), the greenstone belts were emplaced along tensional zones equivalent to a present-day rift zone, and big shield volcaneous erupted over the sialic crust along a strongly fractured zone.

Rybakov (1981 b) has proposed the same mode of emplacement for the greenstone belts of Soviet Karelia. According to him the linear shape is a consequence of its emplacement along a rift system, but it does not reflect the real shape and extent of the whole volcanic complex.

The above is a strong indication that the Kuhmo-Suomussalmi greenstone belt was emplaced in a protorift environment. The rift was formed in a sialic crust and was very probably induced by the uprising of a mantle plume. The assumption of a mantle plume is necessary to explain the komatiitic magmatism. Indeed, the genesis of komatiitic melts implies large degrees of partial melting of a pyrolite and correlated high temperatures $\left(1800^{\circ}-1900^{\circ} \mathrm{C}\right)$ and high pressures. Thus the komatiitic melts 
are considered to be generated at great depth at about $400 \mathrm{~km}$ (Nesbitt and Sun 1976; Nesbitt et al. 1979) 150 to $400 \mathrm{~km}$ (Nisbet 1982). The uprising of a mantle diapir creates a thermal anomaly which can cause a reduction of the crustal thickness and lead to the development of a rift into a sialic crust (Birckle et al. 1975; Condie 1975, 1980, 1981; Nesbitt et al. 1979; Nisbet, 1982). Yet the mantle plume activity took place within a small time range and the volcanic acitivity of the Kuhmo-Suomussalmi greenstone belt was restricted to a single sequence (komatiites, tholeiites, intermediate and acid volcanics) whereas in many other greenstone belts all over the worlds the plume activity lasted a longer time and gave rise to several volcanic sequences. This type of mantle plume activity has been interpreted as that of pulsating migrating mantle plumes (e.g. Condie 1975, 1980; Condie and Hunter 1976; Arth and Hanson 1975; Goodwin 1979; Capdevila et al. 1982). Short-lived mantle plume activity explains why the Kuhmo-Suomussalmi volcanic activity ended at the protorift stage.

In recent years, some authors (e.g. Allegre 1982) have proposed the subduction of an ultramafic plate as a likely mechanism for the generation of komatiitic melt. It, however, the characteristics of the volcanics of the lower sequence of the Kuhmo-Suomussalmi greenstone belt are consistent with a proto-oceanic rift environment, a subduction geotectonic environment is precluded for this belt.

\section{Calc-alkaline magmatism.}

Calc-alkaline magmatism comprises the upper volcanic sequence of the Kuhmo-Suomussalmi greenstone belt and the late "granitic» plutons.

\section{Constraints.}

The calc-alkaline magmatic rocks were emplaced as andesites, dacites and rhyolites over the mafic and ultramafic lavas of the lower volcanic sequence of the Kuhmo-Suomussalmi greenstone belt, and as granodiorites and

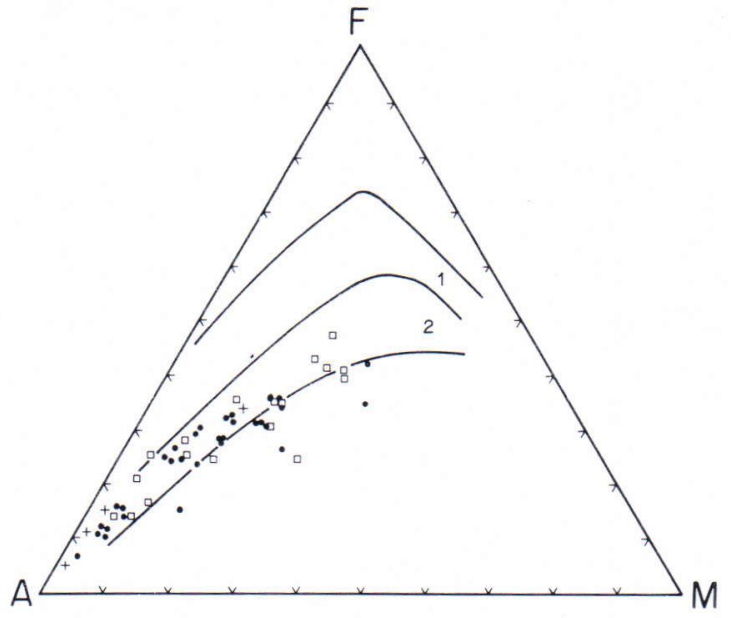

Fig. 6. A F M diagram showing that the acid and intermediate magmas, emplaced after deposition of the lower volcanic sequence of the Kuhmo-Suomussalmi greenstone belt, belong to a calc-alkaline trend. 1 = tholeiitic field; 2 = calc-alkaline field; open circles = acid and intermediate volcanics; filled circles augen gneisses; crosses $=$ pinkish granites.

granites intruding both the belt and its basement. The calc-alkaline geochemical cahracter of this magmatism has been proposed by many authors (Lobach-Zhuckenko et al. 1976; Blais et al. 1977 a, 1977 b; Gaál et al. 1978; Jahn et al. 1980; Vidal et al. 1980; Auvray et al. 1982; Martin and Quérré 1984). Fig. 6 clearly corroborates the calc-alkaline affinities of this magmatism.

Calc-alkaline magmatism is geographically associated with the greenstone belt. 1) The acid and intermediate volcanics are located in the upper part of the greenstone belt itself. They crop out mainly in the northern part of the belt (north of Suomussalmi), which is less deeply eroded. Schematically they occupy the core of the synform structure of the belt (Fig. 5). Acid and intermediate volcanics are unknown outside the belt (on the basement for instance).

2) The maps of the area studied (Wilkman 1921, 1924; Matisto 1954; Hyppönen 1973, 1976, 1978; Hanski 1979; Taipale 1979; Tuokko 1979) and our own field observations in Karelia 


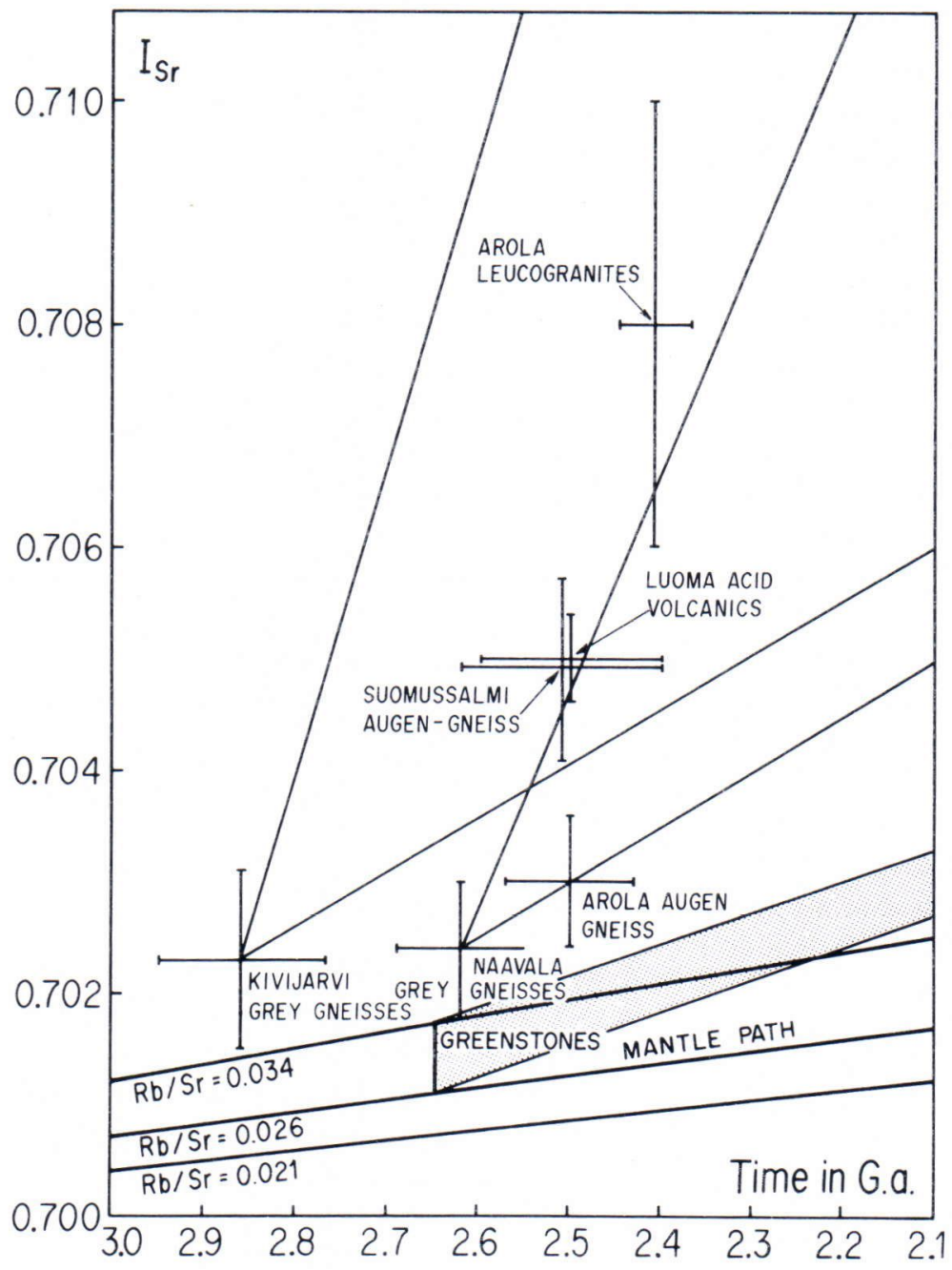

Fig. 7. $\mathrm{I}_{\mathrm{Sr}}-\mathrm{T}$ plot for Archaean rocks of Finland. The ${ }^{87} \mathrm{Sr} /{ }^{86} \mathrm{Sr}$ trends are shown assuming $\mathrm{Rb} / \mathrm{Sr}$ rations equal to the population ratio average plus or minus the standard deviation $(\chi+\sigma$ and $\chi-\sigma)$. clearly indicate that the granodiorites (now augen gneisses) and the granites (pink) are intruded: (a) sometimes into the Kuhmo-Suomussalmi belt, (b) more often into the basement, in the immediate vicinity of the belt, (c) but mostly into the belt-basement contact. In the latter case, some plutons are deformed by vertical shearing wheras others obliterate these tectonic structures. The model that will be proposed must take into account this geographic repartition of the greenstone-calc-alkaline rocks association.

The ${ }^{87} \mathrm{Sr} /{ }^{86} \mathrm{Sr}$ initial ratios $\left(\mathrm{I}_{\mathrm{Sr}}\right)$ of the calc- alkaline rocks are intermediate to high (1) 0.703: Arola augen gneiss; (2) 0,705; Suomussalmi augen gneiss and (3) 0.705 Luoma acid volcanics; (4) 0.708: Arola pink granite (Martin et al. 1983 a; Martin and Quérré 1984). Fig. 7, clearly shows that the $\left(\mathrm{I}_{\mathrm{Sr}}\right)$ of the calc-alkaline magmatic rocks preclude their derivation from the mantle of from the recycling of the lavas of the lower sequence of the greenstone belt, the ${ }^{87} \mathrm{Sr} /{ }^{86} \mathrm{Sr}$ ratios of these two possible sources being too low at the time of emplacement $(2.5$ G.a.) of the calc-alkaline magmas. The grey 
gneisses are better candidates for the role of parent rocks, especially the Kivijärvi grey gneisses.

Note, however that the intermediate $0.703 \mathrm{I}_{\mathrm{Sr}}$ of the Arola augen gneiss cannot be explained simply by the partial melting of grey gneisses, whose anatexis should have produced at 2.5 G.a. magmas with $\mathrm{I}_{\mathrm{Sr}}$ higher than 0.703 (from 0.704 to 0.712 ). With respect to $\mathrm{I}_{\mathrm{Sr}}$, the genesis of the calc-alkaline magmas implies the participation of mafic or ultramafic materials. These materials should be components of the lower volcanic sequence of the greenstone belt or younger materials derived directly from the mantle.

However, the bulk of the calc-alkaline volcanic and plutonic rocks were produced by partial melting of the Kivijärvi grey gneisses (Martin et al. 1983 a; Martin and Quérré 1984).

Major and trace element studies lead to the same conclusion (Martin et al. 1983 a, 1983 b; Martin and Quérré 1984). The $\left(\mathrm{Fe}_{2} \mathrm{O}_{3} \mathrm{O}^{*}+\right.$ $\mathrm{MgO})$ contents of the calc-alkaline rocks $(\sim 7.0)$ are significantly higher than those of the grey gneisses $(\sim 3.5)$. The partial melting of low $\left(\mathrm{Fe}_{2} \mathrm{O}_{3}{ }^{*}+\mathrm{MgO}\right)$ rocks cannot gencrate higher $\left(\mathrm{Fe}_{2} \mathrm{O}_{3}{ }^{*}+\mathrm{MgO}\right)$ liquids; thus the grey gneisses are not the only rocks implyed in the calcalkaline magma genesis. These assumptions are corroborated by the Rare Earth (REE) patterns. Geochemical calculations show that the slightly fractionated REE patterns of the Suomussalmi augen gneiss $\left.(\mathrm{La} / \mathrm{Yb})_{\mathrm{N}}=14-20\right)$ cannot be derived from direct partial melting of the grey gneisses with highly fractionated REE patterns $\left.(\mathrm{La} / \mathrm{Yb})_{\mathrm{N}}=37-103\right)$. Martin et al. $(1983 \mathrm{~b})$ suggest that they were formed by some kind of mixing of the Kivijärvi grey gneisses. Unfortunately these authors have not yet established what the mixing process is? Is it mixing by contemporaneous melting of the basement and of the adjacent greenstone belt? Is it post-anatectic assimilation of mafic enclaves? Or is it mixing by sedimentary processes with subsequent partial melting? Whatever the answer, one thing is true: the petrological and geochemical characteristics of the calc-alkaline magmas can mainly be explained by the partial melting of the Kivijärvi grey gneisses with some participation of greenstone materials. The results clearly show that the greenstone belt and the calc-alkaline magmatic rock association is not only geographic but also genetic.

Normal contacts between the Kuhmo-Suomussalmi greenstone belt and the basement are not known. When not obliterated by the intrusion of granodioritic or granitic plutons, they are strongly deformed by vertical shear zones. The original relationship is therefore masked. These shear zones often appear to be normal faults exhibiting a downward motion of the greenstone belt with respect to the basement (Fig. 5) (Blais et al. 1977 a).

\section{Discussion and model.}

As for the TTG genesis, two main groups of hypothesis can explain the origin and development of the calc-alkaline magmatic activity.

- The genesis of the calc-alkaline magmas is related to subduction zones; they are produced by partial melting of a mafic, descending slab or of a hydrated mantle situated over this slab. In the Kuhmo-Suomussalmi belt the oceanic plate should comprise the mafic and ultramafic volcanics of the lower sequence of the greenstone belt.

During the downward motion of the lower volcanic sequence of the Kuhmo-Suomussalmi greenstone, the base of both the greenstone belt and the sialic crust reached the thermodynamic conditions of partial melting, and thus generated the calc-alkaline magmas.

The former hypothesis, which considers a subduction zone environment for the genesis of calc-alkaline magmas cannot take into account most of the constrainsts discussed previously. This part of the discussion logically follows that concerning the nature and origin of the Kuhmo -Suomussalmi greenstone belt. 
If subduction occurred in this area, the tectonic structures of the belt should be horizontal, just like the belt-basement contact, however they are vertical.

Calc-alkaline magmatism associated with a subduction zone should not have random distribution. The nature and composition of magmatic rocks change over a subduction zone, when the distance from the trench increases; for instance, the $\mathrm{K}_{2} \mathrm{O}$ content increases for the same $\mathrm{SiO}_{2}$ content (e.g. Kuno 1956, 1960; Sugimura 1960, 1968; Dickinson 1968; Miyashiro 1972; Gill 1981). Therefore subduction induce geographical zoning in the magma composition. This type of repartition has not been encountered in Karelia, and there is no indication of zonation in any of the numerous analyses now available. Moreover the calc-alkaline magmas were emplaced into the belt or into the basement in the immediate vicinity of the belt. They are equally distributed on both sides of the belt whereas subduction whould develop magmatism on one side of the trench only.

Geochemical studies demonstrate that the calcalkaline magmas were generated by anatexis of grey gneisses of the Kivijärvi type. In a subduction zone, magmatism is produced by partial melting (1) of the descending oceanic crust (e.g. Coast 1962; Green and Ringwood 1968; Ringwood 1969; Dickinson, 1970) or (2) of the hydrated mantle over the subducted oceanic slab (e.g. Poldervaart 1955; O’Hara 1965; Yoder 1969). This type of genesis conflicts with the geochemical constraints. The molten rocks in a subduction zone are mafic or ultramafic in composition whereas the parent rocks of the calc-alkaline magmas of the Kuhmo-Suomussalmi area are felsic (granodioritic) in composition.

The previous discussion about the greenstone genesis shows that rifting stops at a »protooceanic rift stage» without development of a large ocean. The volume of calc-alkaline plutons implies the melting of large quantities of mafic crust. These two assumptions are incon- sistent and give further evidence against the subduction hypothesis.

Moreover, the lower volcanic sequence of the Kuhmo-Suomussalmi greenstone belt contains large amounts of komatiitic rocks. Could the anatexis of komatiites have generated big volumes of granitoīdes?

The subduction model implies very rapid changes in geodynamic constraints. The protorift stage of spreading, which corresponds to distensive movement, changed in less than 100 M.a. into compressive movement. The plate motion and correlated convection cells should have changed their direction by $180^{\circ}$. This seems to be irrealistic.

The second model (sagduction of the greenstone) takes all the constraints into account and is consistent with the proto-oceanic rifts hypothesis. The lower volcanic sequence of the Kuhmo-Suomussalmi greenstone belt was emplaced over a thinned sialic crust as shield volcanoes along a rift structure and thus created an inverse density gradient. The high-density komatiites $(\sim 3.3)$ and tholeiites ( $\sim 2.9$ to 3.0$)$ overlay the TTG basement with lower density $(\sim 2.7)$; in other words, all along the proto-oceanic rift and over the basement on either side, high-density mafic and ultramafic rocks overlay low-density tonalites and granodiorites. When the volcanic pile has reached its critical thickness (less than 5-7 km according to Gorman et al. 1978), subsidence begins and the greenstone sinks into the sialic crust. The process is like inverse diapirism and is consistent with the experimental models of Ramberg (1967, 1971, 1973). The greenstone »diapir» carries the adjacent sialic crust downwards, which then undergoes partial melting and produces calc-alkaline magmas.

Gorman et al. (1978) considered that before subsidence can begin a volcanic complex emplaced over a sialic crust should be $5-7 \mathrm{~km}$ thick and $50 \mathrm{~km}$ in radius. The present thickness of the Kuhmo-Suomussalmi greenstone belt is estimated to be $5000 \mathrm{~m}$ (Blais et al. 1978) and 5000 à $6000 \mathrm{~m}$ (Taipale et al. 1980). The 
thickness of the greenstone belts in Soviet Karelia is in the same range (Popov et al. 1979; Rybakov et al. 1979, 1980, 1981 a). Moreover, the outcrops of greenstone materials scattered over the gneissic basement corroborate the larger extent of the belt and its emplacement over the basement rocks (Gaál et al. 1976; Rybakov et al. 1981 b). These data are in good agreement with the assumptions of Gorman et al. (1978). The length of time necessary to build a greenstone belt such as the Kuhmo-Suomussalmi one is in the order of 50 M.a. (Arth and Hanson 1975; Gorman et al. 1978).

If the analytical uncertainties are taken into account, 100 M.A. elapsed between the emplacement of the greenstone belt and of the later calc-alkaline magmatism (Martin et al. 1983 a; Martin and Quérré 1984). This value is a maximum; the real time is a good two or three times shorter. The velocity of subsidence ranged between an average of 0.1 and $0.2 \mathrm{~cm}$ year $^{-1}$, assuming a linear geothermal gradient of $30^{\circ} \mathrm{C}$ $\mathrm{km}^{-1}$ and melting temperatures of granodiorites and tonalites of about $850^{\circ} \mathrm{C}$. Although a bit low, the values are in the range of geological phenomenon velocities.

This sag-duction hypothesis explains the field relationships and is consistent with the petrogenetic and geodynamic processes considered for the basement and greenstone belt genesis and evolution.

Because of its high density, the lower volcanic sequence of the Kuhmo-Suomussalmi greenstone-belt set the sad-duction in motion, a process that later led to the genesis of the post-belt magmatism. This explains the geographic and genetic relationship between the lower volcanic sequence of the belt and the calc-alkaline magmatism.

According to the model described by Gorman et al. (1978) and based on the experiments of Ramberg $(1967,1971,1973)$, the belt should be a synform in shape, with sediments in the central part. The folds axis and schistosity and/or foliation planes in the belt should be vertical or subvertical. The model also suggests that the belt-basement contacts should be faulted (normal faults with downward motion of the greenstone). All the experimental results and model proposals are consistent with the constraints discussed in the first part of this chapter.

The model of Gorman et al. (1978) implies the formation of more or less well developed rim symclines on both sides of the belt. The small outcrops of greenstone spread over the basement and mapped by Hyppönen (1973, 1976,1978 ) could be the more or less eroded bottoms of rim synclines.

The melting of the mafic and ultramafic lavas at the base of the subsiding greenstone belt is highly unlikely. The melting temperatures of komatiites and tholeiites are high $\left(1600^{\circ} \mathrm{C}\right.$ and $1000^{\circ} \mathrm{C}$ respectively), whereas those of granodiorites and tonalites range between $800^{\circ}$ and $850^{\circ} \mathrm{C}$. Thus, when the melting temperatures of tholeiites are reached, appreciable amounts of grey gneiss are already molten, and consequently this process cannot explain the participation of rather large amounts of greenstone in the calc-alkaline magmas genesis. Taking thermodynamic constraints into consideration, the more likely process is the assimilation of tholeiitic and/or komatiitic enclaves by calc-alkaline magmas.

The belt-basement contacts are often obliterated by calc-alkaline plutons. This means that the faulted contact probably constituted a zone of weakness that acted as a drain for the calcalkaline magmas. The contact therefore become a preferential zone of intrusion of the magmas. In this zone, some plutons are strongly deformed by shearing; others are not. This clearly demonstrates that the calc-alkaline magmatic rocks developed over a long period. The subsidence of the lower volcanic sequence of the Kuhmo-Suomussalmi greenstone belt continued after the begining of sialic anatexis at depth.The first magmas generated were emplaced at the belt-basement contact, where they were subsequently deformed by the downward 
sagging of the belt. When the last plutons were intruded, subsidence ended, and thus they were not deformed. Their age of 2.5 G.a. could indicate the end of the sagduction process.

Note that the ascending motion of the plutons should accentuate the relative downward motion of the greenstone belt. In conclusion, our present knowledge of this area indicates that the geodynamic model best able to explain the fieldrelationships and the tectonic and geochemical characteristics of the calc-alkaline magmatism is that of sag-duction of the Kuhmo-Suomussalmi greenstone belt.

This process does not imply changes in the regional geodynamic constraints, but is the logical consequence of the emplacement of the lower volcanic sequence of the belt and, therefore, of the rifting process.

\section{Conclusion}

Table I summarizes the chronology of emplacement of the Archaean terrains in Finnish Karelia. Their genesis and evolution can be explained as follows: the older geological events recognized in this area to date are the emplacement of TTG magmas, produced by partial melting of an »oceanic» crust (transformed into garnet-bearing amphibolite). This process occurred in subduction zones and does not necessitate high geothermal gradients $\left(25^{\circ}\right.$ to $30^{\circ} \mathrm{C}$ $\mathrm{km}^{-1}$ ) The TTG plutonic rocks were subsequently transformed into grey gneisses. The accretion of the continental crust operated in at least two processes: 1) production of TTG magmas in subduction zones, and 2) aggregation of small sialic fragments. The latter process could explain: a) the lack of large sutures, which should have been obliterated by successive collisions and (b) the deformation and migmatisation of the Kivijärvi grey gneisses before the emplacement of the Naavala grey gneisses and of the Kuhmo-Suomussalmi greenstone belt. This tectonometamorphic event could be related to a collision between two sialic fragments.

The previously accreted crust was fissured and the lower volcanic (mafic and ultramafic) sequence of the Kuhmo-Suomussalmi greenstone belt emplaced in a proto-oceanic rift environment. The rifting and magmatism were produced by uprising of a mantle diapir with a thermal anomaly, and gave rise to komatiites and tholeiites. The dense komatiitic and tholeiitic lavas overlie the less dense sialic crust and create a density inversion that induced a gravity instability. This produced the downward motion of the lower volcanic sequence of the KuhmoSuomussalmi greenstone belt.

Downward diapirism then carried the greenstone and the adjacent basement to depth, where they later underwent partial melting and generated the calc-alkaline magmas. Participation (assimilation) of mafic components is implied in association with this process. The magmas moved up to the surface and were emplaced as volcanics into the belt and as plutons into the basement in the immediate vicinity of the belt.

Discussion of the different models points to the occurrence of Archaean plate tectonics in this part of eastern Finland. Nevertheless one aspect of the discussion appears to be inconsistent with the constraints. The geothermal gradient in the crust and in subduction zones was indentical to the present one $\left(25^{\circ}\right.$ to $30^{\circ} \mathrm{C}$ $\mathrm{km}^{-1}$ ), whereas in the rift zones it had higher values, thereby permetting the genesis and emplacement of komatiites. Moreover, heat generation is supposed have played a more important role in Archaean time than in present days (MacKenzie and Weiss 1975; Lambert 1976). With regard to the latter assumptions, a worldwide high geothermal gradient could be imagined, but unfortunately it would be inconsistent with the $25^{\circ}-30^{\circ} \mathrm{C} \mathrm{km}-1$ assessed by many authors (Wells 1976; Burke and Kidd 1978; Condie 1980, 1981; this paper). So, for lack of a uniform geothermal gradient, we have to imagine two categories of thermal zones: 
- Larges ones with a »normal» $25^{\circ}-30^{\circ} \mathrm{C}$ $\mathrm{km}^{-1}$ geothermal gradient, correlated with a thick crust.

- Smaller ones, with a high geothermal gradient, which would act as an outlet for the heat of the Earth; they could well be rift zones and correspond to thin crust.

The geothermal gradient has remained the same over most of the Earth since at least mid to late-Archaean time, but more would have escaped through rifts at that time than nowadays. This is corroborated by the emplacement of high temperatures magmas, such as the komatiitic series, which have been almost unknown on Earth since Archaean time.

Nevertheless the high geothermal gradients of the rift zones cannot alone explain the spreading of all heat production; this could only have happened with longer rift zones. With respect to the present day plate tectonics the best way to lengthen the rifts was to have a greater number of plates. The surface of the earth being constant, an increase in the number of plates implies that the plates were smaller.

\section{References}

Allegre, C. J., 1982. Genesis of Archaean komatiites in a wet ultramafic subducted plate. In komatiite volume. (N. T. Arndt and F. G. Nisbet (editors). George Allen and Unwin, London, 495-500.

Anhaeusser, C. R.; Mason, R.; Viljoen, M. J. \& Viljoen, P. $P ., 1969$. A reappraisal of some aspects of Precambrian shield geology. Geol. Soc. Am. Bull. 80, 2175-2200.

Arndt, N. T., 1977. Thick, layered peridotite-gabbro lava flows in Munro Township, Ontario, Can. J. Earth Sci. $14,2620-37$.

Arth, J. G., 1979. Some trace elements in trondhjemites their implications to magma genesis and paleotectonic setting in F. Barker (editor), Trondhjemites dacites and related rocks. Elsevier, Amsterdam 123-132.

Arth, J. G. \& Hanson, G. N., 1975. Geochemistry and origin of the early Precambrian crust of northeastern Minnesota. Geochim. Cosmochim. Acta 39, 325-362.
In summary, plate tectonics acted in Archaean times, but althrough the general scheme appears to have been the same it is to day, some details were different (geothermal gradients, number and size of plates, etc...).

This general model of geodynamic evolution of the Archaean crust in eastern Finland takes into account a maximum number of field, tectonic, petrological, geochemical, geochronological constraints; with our present knowledge, it is therefore reasonable. Nevertheless since it reflects our present concepts and the scope of current research it will have to be modofied or distroyed if required by new data. That is geological model behaviour.

Acknowledgments. This work was financed under a joint research agreement between the Academy of Finland and the French »Ministères des Relations Extérieures» We wish to thank the Geological Survey of Finland for their kind cooperation.

Helpful discussions with J.M. Bertrand, D. Bridgwater and G. Gaál were very much appreciated. We also thank A. Falaise for her efficient typing.

Auvray, B.; Blais, S.; Jahn, B. M. \& Piquet, D., 1982. Komatiites and komatiitic series of the finnish greenstone belts. In: komatiite volume (ed. N. T. Arndt and N. Nisbet), $131-146$.

Ayrey, L. D., 1977. Importance of stratigraphy in early Precambrian volcanic terrains: cyclic volcanism at Setting Net Lake, northwestern Ontario. Geol. Assoc. Can. Spec. Paper 16, 243-264.

Barbey, $P$., 1982. Signification geodynamique des domaines granulitiques. La ceinture des granulites de Laponie (Fennoscandie): une suture de collision continentale d'age proterozoigue inferieur (2.3-1.9 GA). Reconstitution geochimique et petrologique. Unpublish. Thesis, Nancy 346 p.

Barbey, P.; Convert, J.; Martin, H.; Moreau, B.; Capdevila, R. \& Hameurt, J., 1980. Relationships between granite-gneiss terrains, greenstone belts and granulite belts in the archaean crust of Lapland (Fennoscandia). Geol. Rundsch. 69, 3, 648-658. 
Barbey, P.; Capdevila, R. \& Hameurt, J., 1982. Major and transition trace element abundances in the khondalite suite of the granulite belt of Lapland (Fennoscandia): evidence for an early Proterozoic flysh belt. Precambrian Res. 16, 273-290.

Barbey, P.; Touret, L.; Capdevila, R. \& Hameurt, J., 1982. Mise en evidence de deux series paleo-volcaniques dans la ceinture proterozoique de la Tana. Consequence sur l'environment geotectonique de la ceinture des granulites de Laponie. (Fennoscandie). C.R. Acad. Sc. Paris 294, D, 207-210.

Barker, F., 1979. Trondhjemite: definition, environment and hypothesis of origin. In: Trondhjemites, dacites and related rocks. (ed. Barker F.), 1-12, Elsevier.

Barker, F. \& Arth, J. G., 1976. Generation of trondhjemitic -tonalitic liquids and Archaean bimodal trondhjemitebasalt suites. Geology 4, 596-600.

Bebien, J., 1973. Geochimie des roches volcaniques oceaniques: comparaison des volcanismes actuels et ophiolitiques. C.R. Aca. Sci. Paris 276, D, 3111-3114.

Bernard-Griffiths, J.; Peucat, J. J.; Postaire, B.; Vidal, Ph.; Convert, J. \& Moreau, B., 1984. Isotopic data $(\mathrm{U}-\mathrm{Pb}, \mathrm{Pb}-\mathrm{Sr}, \mathrm{Pb}-\mathrm{Pb}$ and $\mathrm{Sm}-\mathrm{Nd}$ ) on mafic granulites from Finnish Lapland. Precambrian Res. 23, 325-348.

Bertrand, J. M.; Blais, S. \& Capdevila, R., 1978. Precision sur l'evolution structurale de l'Archeen de Karelie (Finlande). C.R. Acad. Sci. Paris 287, 683-686.

Bibikova, E. V. \& Tugarinov, A. I., 1975. Geochronology of the White Sea Block. In: Recent Contributions to Geochemistry and Analytical Chemistry, p. 471-480. Wiley.

Bickle, M. J.; Martin, A. \& Nisbet, E. G., 1975. Basaltic and peridotitic komatiites and stromatolites above a basal unconformity in the Belingwe greenstone belt, Rhodesia. Earth Planet. Sci. Lett. 27, 155-162.

Blais, S.; Auvray, B.; Capdevila, R. \& Hameurt, J., 1977 a. Les series komatiitiques et tholeiitiques des ceintures archeennes de roches vertes de Finlande orientale. Bull. Soc. Geol. France 19, 965-970.

Blais, S.; Auvray, B.; Bertrand, J. M.; Capdevila, R.; Hameurt, J. \& Vidal, Ph., 1977 b. Les grands traits geologiques de la ceinture archeenne de roches vertes de Suomussalmi-Kuhmo (Finlande orientale). Bull. Soc. Geol. France 19, 1033-1039.

Blais, S.; Auvray, B.; Capdevila, R.; Jahn, B. M. \& Hameurt, J. 1978. The archaean greenstone belts of Karelia (Eastern Finland) and their komatiitic and tholeiitic series. In: Archaean geochemistry (ed. B. F. Windley and M. Naqvi), 87-107. Elsevier.

Bowes, D. R., 1976. Archaean Crustal History in the Baltic Shield. In The Early History of the Farth (ed. B. F. Windley), pp. 481-488. Wiley.

Bungum, H., Pirhonen, S. E.\& Husebye, E. S., 1980. Crus- tal thickness in Fennoscandia. Geophys. J.R. astr. Soc. $63,759-774$.

Burke, K.; Dewey, J. F. and Kidd, W. S. F., 1976. Dominance of horizontal movements, arc and microcontinental collisions during the later permobile regime. In: B. F. Windley (editor). The Early History of the Farth. Wiley, London, p. 113-129.

Burke, K. \& Kidd, W. S. F., 1978. Were Archaean continental geothermal gradients much steeper than those of today? Nature 272, 240-241.

Calganile, G., 1982. The lithosphere - astenosphere system in Fennoscandia. Tectonophysics 90, 19-35.

Capdevila, R.; Goodwin, A. M.; Ujike, O. \& Gorton, M. $P ., 1982$. Trace element geochemistry of Archaean volcanic rocks and crustal growth in southwestern Abitibi belt, Canada. Geology 10, 418-422.

Coast, R. P., 1962. Magma type and crustal structure in the Aleutian arc. In: Crust of the Pacific basin. Geophys. Monogr. Am Geophys. Union. 6, 92-109.

Condie, K. C., 1975. A mantle plume model for the origin of Archaean greenstone belts based on trace element distributions. Nature 258, p. 413-414.

-, 1980. Origin and early development of the earth's crust. Precambrian Res. 11, 183-197.

-, 1981. Archaean greenstone belts. Developments in Precambrian geology V 3, Windley, B. F. (editor) 434 p.

Condie, K. C. \& Hunter, D. R., 1976. Trace-element geochemistry of Archaean granitic rocks from the Barberton region, South Africa. Earth Planet. Sci. Lett. 29, $389-400$.

Convert, J., 1981. Les granulites a orthopyroxene de Laponie (Finlande et Norvege). Petrologie et geochimie. Unpublish. Thesis, Rennes, $181 \mathrm{p}$.

Cooper, J. A.; Nesbitt, R. W.; Platt, J. P. \& Mortimer, G. $E ., 1978$. Crustal development in the Agnew region western Australia, as shown by $\mathrm{Rb} / \mathrm{Sr}$ isotopic and geochemical studies. Precambrian Res. 7, 31-59.

Cuney, M. \& Barbey, P., 1982. Mise en evidence de phenomenes de cristallisation fractionnee dans les migmatites. C.R. Acad. Sc. Paris 295, D, 37-42.

Dickinson, W.R., 1968. Circum-Pacific andesite types. J. Geophys. Res. 73, 2261-2269.

-, 1970. Relations of andesites, granites and derivative sandstones to arc-trench tectonics. Rev. Geophys. Space Phys. 8, 813-860.

Elder, J. $W ., 1972$. Dynamic control of magmatic processes J. Earth. Sci., Leeds, Univ. 8, 287-303.

Engel, A. E.; Itson, S. P.; Engel, C. G.; Stickney, D. M. \& Cray, E. J., Jr. 1974. Crustal evolution and global tectonics a petrographic view. Bull. geol. Soc. Amer. 85, $843-858$.

Eskola, P., 1963. The Precambrian of Finland. In: The geologic systems. The precambrian, Rankama M. (Ed.), Wiley, New-York, 145-266. 
Flyod, P. A. \& Winchester, J. A., 1975. Magma type and tectonic setting discrimination using immobile elements. Earth Planet. Sci. Lett. 27, 211-218.

Forsythe, D. \& Uyedas, S. 1975. On the relative importance of driving forces of plate motion. J. Geophys. Res. 43, $163-200$.

Frosterus, B. \& Wilkman, W. W., 1920. Kivilajikartan selitys D3, Joensuu. Suomen geologinen yleiskartta, 1 : 400 000. Geologinen tutkimuslaitos.

Gaál, G.; Mikkola, A. \& Söderholm, B., 1976. Development of the Archaean crust in Finland. 25th Intern. Geol. Congr. Sydney 1, 8-9.

Gaál, G.; Mikkola, A. \& Söderholm, B., 1978. Evolution of the archaean crust in Finland. Precambrian Res. 6, $199-215$.

Garcia, O. M., 1978. Criteria for the indentification of ancient volcanic arcs. Earth Science Review 14, 147-167.

Gill, J., 1981. Orogenic andesites and plate tectonics. Springer Verlag. Berlin. Heidelberg. New York. 390 p.

Glassey, W. E., 1974. Geochemistry and tectonics of the crescent volcanic rocks, Olympic Peninsula, Washington, Geol. Soc. Amer. Bull. 85, 785-794.

Glikson, A. Y., 1970. Geosynclinal evolution and geochemical affinities of early Precambrian systems. Tectonophysics 9, 397-433.

_, 1972. Early Precambrian evidence of a primitive ocean crust and island nuclei of sodic granite. Geol. Soc. Am. Bull. 83, 3323-3344.

-, 1973. Primitive Archaean element distribution patterns: chemical evidence and geotectonic significance. Earth Planet. Sci. Lett. 12, 309-320.

-, 1979. Early precambrian tonalite-trondhjemite sialic nuclei. Earth-Science Reviews 15, 1-73.

Goodwin, A. M., 1973. Archaean iron-formations and tectonic basins of the Canadian Shield. Econ. Geol. 68, 915 -933. Shield.

- 1979. Archaean volcanic studies in the Timmins-Kirkland Lake-Noranda region of Ontario and Quebec. Geol. Surv. Can. Bull. 278, 51 p.

Goodwin, A. M. \& Ridler, R. H., 1970. The Abitibi orogenic belt. Geol. Surv. Can. Pap. 70-40, 1-24.

Gorman, B. E.; Pearce, T. H. \& Birkett, T. C., 1978. On the structure of Archaean greenstone belts. Precambrian Res. 6, 23-41.

Green, N. L., 1975. Archaean glomeroporphyritic basalts. Can. J. Earth Sci. 12, 1770-1784.

Green, T. H. \& Ringwood, A. Y., 1968. Genesis of the calcalkaline igneous rock suite. Contrib. Mineral. Petrol. 18, 105-162.

Hanski, E. J., 1979. Komatiittiset ja tholeiittiset vulkaniitit Siivikkovaaran alueella Kuhmon arkeisella vihreäkivivyöhykkeellä Kuhmon ja Kittilän malmiprojektit. Oulun Yliopisto. Raportti 15, 106 p.

Hanski, E. J., 1980. Komatiitic and tholeiitic metavolcanics of the Siivikkovaara area in the Archaean Kuhmo greenstone belt, Eastern Finland. Bull. Geol. Soc. Finland 52, 67-100.

Hanson, G. N., 1980. Rare Earth elements in petrogenetic studies of igneous systems: Annual review of Arth and Planetary Sciences 8, 371-406.

Hart, S. R. \& Brooks, C., 1977. The geochemistry and evolution of early Precambrian mantle. Contrib. Mineral. Petrol. 61, 109-128.

Hubregtse, J. J., 1976. Volcanism in the western Superior Province in Manitoba. In: B. F. Windley (editor). The early history of the Earth. J. Wiley and Son, New York, N.Y. 279-288.

Hyppönen, V., 1973. Kallioperäkartta, lehti 4412. Hiisijärvi. Suomen geologinen kartta, $1: 100$ 000, Geologinen tutkimuslaitos.

—, 1976. Kallioperäkartta, lehti 4411, Ontojoki. Suomen geologinen kartta, 1 : 100 000, Geologinen tutkimuslaitos.

—, 1978. Kallioperäkartta, lehti 4413, Kuhmo. Suomen geologinen kartta, 1 : 100 000, Geologinen tutkimuslaitos.

Jahn, B. M., 1977. Trace element geochemistry of Archaean volcanic rocks and its implications for the chemical evolution of the upper mantle. Bull. Soc. geol. France 6, 1259-1269.

Jahn, B. M.; Shih, C. Y. \& Murthy, V. R. 1974. Trace element geochemistry of Archaean volcanic rocks. Geochim. Cosmochim. Acta 38, 611-627.

Jahn, B. M. \& Nyqvist, L. E., 1976. Crustal evolution in the early earth moon system: constraints from $\mathrm{Rb}-\mathrm{Sr}$ studies. In: The early history of the earth (ed. B. F. Windley). John Wiley and Sons, London, 55-76.

Jahn, B. M.; Auvray, B.; Blais, S.; Capdevila, R.; Cornichet, J.; Vidal, F. \& Hameurt, J., 1980a. Trace element geochemistry and petrogenesis of finnish greenstone belts. Journ. Petrol. 21, 201-244.

Jahn, B. M.; Vidal, P. \& Tilton, G., 1980 b. Archaean mantle heterogeneity: evidence from chemical and isotopic abundances in Archaean igneous rocks. Phil. Trans. R. Soc. A 297, 353-64.

Jahn, B. M.; Glikson, A. Y.; Peucat, J. J. \& Hickman, A. $H ., 1981$. REE geochemistry and geochronology of Archaean silicic volcanics and granitoids from the Pilbara block, Western Australia. Geochim. Cosmochim. Acta $45,1633-1652$.

Jahn, B. M.; Gruau, G. \& Glikson, A. Y., 1982. Komatiites of the Onverwacht group, S. Africa: REE geochemistry, $\mathrm{Sm} / \mathrm{Nd}$ Age and mantle evolution. Contrib. Mineral. Petrol. 80, 25-40.

Kouvo, O., 1958. Radioactive age of some Finnish Precambrian minerals. Bull. Comm. geol. Finlande. 182.

—, 1965. Geological Survey annual report. 1964. Otaniemi. 
Kouvo, O. \& Tilton, G. R., 1966. Mineral ages from the Finnish Precambrian J. Geol. 74, 421-442.

Kröner, A.; Puustinen, K. \& Hickman, M., 1981. Geochronology of an archaean tonalitic gneiss dome in northern Finland and its relation with an unusual overlaying volcanic conglomerate and komatiitic greenstone. Contr. Mineral. Petrol. 76, 33-41.

Kuno, H., 1959. Origin of cenozoic petrographic provinces of Japan and surrounding areas. Bull. Volc. 20, 37-76.

—, 1960. High alumina basalt. J. Petrol. 1, 121-145.

Lambert, R. S. J., 1976. Archaean thermal regimes, crustal and upper mantle temperatures, and a progressive evolutionary model for the earth. In: (B. F. Windley Editor). The Early History of the Earth Wiley, London, pp. $363-387$.

Lambert, I. B. \& Wyllie, P. J., 1968. Stability of hornblende and a model for the velocity zone. Nature, 219, $1240-1241$.

Le Pichon, X., 1968. Sea-floor spreading and continental drift J. Geophys. Res. 73. 3661-3697.

Lobach-Zhuckenko, S. B.; Krylov, I. N.; Baykova, V. S.; Chekulaev, V. P.; Arestova, N. A. \& Shuleshko, I. K., 1976. The geological evolution of the Karelian greenstone terrain of the Baltic shield. 25th Intern. geol. Congr. Sydney 1, 16-17.

Malløe, S. \& Petersen, T. S., 1981. Petrogenesis of oceanic andesites. J. Geophys. Res. 86, 10273-10286.

Martin, H.; Chauvel, C.; Jahn, B. M. \& Vidal, Ph., 1983 a. $\mathrm{Rb} / \mathrm{Sr}$ and $\mathrm{Sm} / \mathrm{Nd}$ isotopic ages and geochemistry of archaean granodioritic rocks from eastern Finland. Precambrian Res. 20, 79-91.

Martin, H.; Chauvel, C. \& Jahn, B. M., 1983 b. Major and trace element geochemistry and crustal evolution of archaean granodioritic rocks from eastern Finland. Precambrian Res. 21, 159-180.

Martin, H. \& Quérré, G., 1981. A 2.5 Ga reworked sialic crust. $\mathrm{Rb}-\mathrm{Sr}$ ages and isotopic geochemistry of late Archaean volcanic and plutonic rocks from E. Finland Contrib. Mineral. Petrol. 85, 292-299.

Matisto, A., 1958. Kivilajikartan selitys D5, Suomussalmi. With an english summary: Explanation of the maps of rocks: Suomen geologinen kartta, 1 : 100 000. Geologinen tutkimuslaitos.

Miyashiro, A., 1972. Metamorphism and related magmatism in plate tectonics. Amer. J. Sci. 272, 629-656.

Moorbath, S., 1977. Ages, isotopes and the evolution of Precambrian crust. Chem. Geol. 20, 151-187.

Moorbath, S.; O'Nions, R. K.; Pankhurst, R. J.; Gale, N. H. \& Mac Gregor, V. P., 1972. Further rubidiumstrontium age determinations of the very early Precambrian rocks of the Godthaab district, Western Greenland. Nature Phys. Sci. 240, 78-82.

Moreau, B., 1980. Petrologie et geochimie des anorthosites de Laponie (Finlande): exemple des masssifs de Vaskojoki et de Mutajärvi Unpublish. Thesis, Rennes, 267 p.

Moreau, B., 1981. Evolution du massif anorthositique de Vaskojoki, (Finlande du Nord). Annales de la Soc. Geol. de Belgique 104, 261-267.

Mutanen, T., 1976. Komatiites and komatiite provinces in Finlande. Geologi 28, 49-56.

McKenzie, D. P. \& Weiss, N., 1975. Speculations on the thermal and tectonic history of the earth. Geophys. J. R. Astron. Soc. 42, 131-174.

Naldrett, A. J. \& Turner, A. R., 1977. The geology and petrogenesis of a greenstone belt and related nickel sulfide mineralization at Yakabindie, western Australia. Precambrian Res. 5, 43-103.

Nesbitt, R. W. \& Sun, S. S., 1976. Geochemistry of Archaean spinifex-textured peridotites and magnesian and low-magnesian tholeiites. Earth planet. Sci. Lett. 31, $433-53$

Nesbitt, R. W., Sun, S. S. \& Purivs, A. C., 1979. Komatiites: geochemistry and genesis. Can. Mineral. 17, 165186.

Nisbet, E. G., 1982. The tectonic setting and petrogenesis of komatiites. In: komatiite volume. N. T. Arndt and E. G. Nisbet (editors) George Allen and Unwin, London. $501-518$.

O'Hara, M. J., 1965. Primary magmas and the origin of basalts. Scott. J. Geol. 1, 19-40.

O'Hara, M. J. \& Yoder, H. S. Jr., 1963. Partial melting of the mantle: Carnegie Inst. Washington Year Book 62, 67-71.

O'Nions, R. K. \& Pankhurst, R. J., 1978. Early archaean rocks and geochemical evolution of the Earth's crust. Earth. Planet. Sci. Lett. 38, 211-235.

Oxburgh, E. R., 1974. The plain man's guide to plate tectonics. Proc. Geol. Assoc. 85, 299-357.

Patchett, P.; Kouvo, O.; Hedge, C. \& Mitsunobu, T., 1981. Evolution of Continental crust and mantle heterogeneity: Evidence from $\mathrm{Hf}$ isotopes. Contrib. Mineral. Petrol. 78, 279-297.

Pearce, J. A. \& Cann, J. R., 1973. Tectonic setting of basic volcanic rocks determined using trace element analyses. Earth Planet. Sci. Lett. 19, 290-300.

Peucat, J. J. \& Martin, H., 1984. Are Rb-Sr thin slabs migmatites ages meaningful? Evidence provided by three examples in metamorphic basement complexes of various ages. N. Jhr. Miner Monat. (in press)

Piper, J. D. A., 1976. Paleomagnetic evidence for a Proterozoic supercontinent. Philos. Trans. R. Soc. London A 280, 469-490.

Piquet, D., 1982. Mecanismes de recristallisation metamorphique dans les ultrabasites: exemple des roches vertes archeennes de Finlande Orientale (ceintures de Suomussalmi-Kuhmo). Unpublished thesis, Rennes, 246 p. 
Poldevaart, A., 1955. Chemistry of the earth's crust. Geol. Soc. Am. Mem. 62, 119-144.

Popov, M. G.; Suholetova, G. N. \& Morozov, S. A., 1979. Geology of the Kanenho zersky region. (in Russian). In: Geology of early Precambrian rocks of Karelia. Petrodzavodsk, 76-94.

Quérré, G., 1981. Resultats preliminaires sur la petrologie des intrusions granitiques "tardives» dans les terrains archeens du Kainuu (Finlande orientale) (abstract). E.U.G., Strasbourg, p. 113.

Ramberg, H., 1967. Gravity, deformation, and the Earth's crust. Academic Press, London, 214 p.

,- 1971 . Model studies in relation to intrusion of plutonic bodies. In: G. Newall and N. Rast (Editors), Mechanism of Igneous Intrusion, Geol. Journ., Spec. Issue 2, 261 p.

-, 1973. Model studies of gravity-controlled tectonics by the centrifuge technique. In: K. A. de Jong and R. Scholten (Editors), Gravity and Tectonics, John Wiley, New York, N.Y. 49-66.

Ringwood, A. E., 1969. Composition and evolution of the upper mantle. In: P. J. Hart, Ed., The Earth's Crust and Upper Mantle. p. 1-21. Am. Geophys. Monogr. 13.

Rutland, R. W. R., 1973. Tectonic evolution of the continental crust of Australia. In: D. H. Tarling and S. K. Runcorn (editors), Implications of Continental Drift to the Earth Sciences. Academic Press, London, pp. 1011 -1033 .

Rybakov, S. I., 1980. Metamorphism of early Precambrian sediments and volcanic suites in Karelia. Petrodzavodsk 133 p. (in Russian).

Rybakov, S. I.; Sviridenko, L. P. \& Svetova, A. I., 1979. Petrogeosynclinal rocks of central and south Karelia in connection with greenstone belts (in Russian). In: Geology of early Precambrian rocks of Karelia, Petrodzavodsk, 6-22.

Rybakov, S. I. \& Lobach-Zhuckenko, S. B., 1981 a. Geological, geochemical and geophysical investigations in the eastern part of the Baltic shield. 10th general meeting of the Finnish. Soviet joint geological working group. 19-41.

Rybakov, S. I.; Kulikov, V. C. \& Robonen, V. I., 1981 b. The volcanism in Archaean greenstone belts of Karelia (in Russian), Nauka, 152 p.

Sederholm, J. J., 1897. Über eine archaische sediment formation in Südwestlichen Finnland und ihre Bedeutung für die Erklärung der Enstehungsweise des Grundgebierges. Bull. Comm. geol. Finlande n. 36.

- , 1932. On the geology of Fennoscandia. Bull. Comm. geol. Finland 98.

Shaw, D. M., 1970. Trace element fractionation during anatexis. Geochim. Cosmochim. Acta 34, 237-242.

Stern, C. R., Huang, W. \& Wyllie, P. F., 1975. Basalt andesite - rhyolite $-\mathrm{H}_{2} \mathrm{O}$ : crystallization intervals with excess $\mathrm{H}_{2} \mathrm{O}$ and $\mathrm{H}_{2} \mathrm{O}$ - undersaturated liquidus surfaces to $35 \mathrm{kbars,}$ with implications to magma genesis. Earth Planet. Sci. Lett. 28, 189-196.

Sugimura, A., 1960. Zonal arrangement of some geophysical and petrological features in Japan and its environs. J. Fac. Sci. Univ. Tokyo, Sect. 2, 12, 133-153.

-, 1968. Composition of primary magmas and seismicity of earth's mantle in island arcs. Geol. Soc. Can. Pap., 66-15. 337-346.

Sun, S. S. \& Nesbitt, R. W., 1977. Chemical heterogenity of the Archaean mantle, composition of the Earth and mantle evolution. Earth Planet. Sci. Lett 35, 429-448.

Sun, S. S. \& Nesbitt, R. W.; 1978. Petrogenesis of Archaean ultrabasic and basic volcanics: evidence from the rare elements. Contrib. Mineral. Petrol. 65, 301-325.

Sutton, J., 1976. Tectonic relationships in the Archaean. In: B. F. Windley (editor), The early history of the Earth. J. Wiley and Sons, New York, N.Y., 99-104.

Taipale, K., 1979. Arkeisen vulkanismin kehitys Tipasjärven alueella. Kuhmon ja Kittilän malmiprojektit, Oulun Yliopisto, Raportti no 14.

Taipale, K.; Tuokko, I. \& Piirainen, T., 1980. A brief introduction to the geology and geochemistry of the Kuhmo greenstone belt, Eastern Finland. In: IGCP projet n. 161. field excursion guide for Finland. (ed. H. Papunen) $37-73$.

Talbot, C. J., 1973. A plate tectonic model for the Archaean crust. Phil. Trans. R. Soc. Lond. A 273, 413428.

Tarney, J., 1976. Geochemistry of high-grade gneisses, with implications as to the origin and evolution of the Precambrian crust. In: B.FG. Windley (editor). The early history of the Earth. J. Wiley and Sons, New York, NB.Y. 405-417.

Tarney, J.; Dalziel, I. W. D. \& Dewit, M. J., 1976. Marginal basin »Procas Verdes» complex from S. Chile: A model for Archaean greenstone belt formations. In: B. F. Windley (editor). The Early History of the Earth. Wiley, London, p. 131-146.

Tuokko, I., 1979. Kuhmon-Suomussalmen Liuskejakson rautamuodostumat ja niiden stratigrafinen sijainti. Kuhmon ja Kittilän malmiprojektit, Oulun Yliopisto, Raportti no 16.

Vaasjoki, M., 1981. The lead isotopic composition of some Finnish galenas. Geol. Surv. Finland Bull. 316, 1-30.

Vartiainen, H., 1970. Schist belt of Tipasjärvi in the parish of Sotkamo, Finland. Bull. Geol. Soc. Finland 42, $13-22$.

Väyrynen, H., 1933. Über die Stratigraphic der Karelischen Formation. Bull. Comm. Geol. Finland 101, 54-78.

-, 1954. Suomen Kallioperä. Otava Helsinki.

Vidal, Ph.; Blais, S.; Jahn, B. M.; Capdevila, R. \& Tilton, G. $R ., 1980 . \mathrm{Pb}-\mathrm{Pb}$ and $\mathrm{Rb}-\mathrm{Sr}$ systematics of the 
Suomussalmi archaean greenstone belt (eastern Finland). Geochim. Cosmochim. Acta 44, 2033-2044.

Wells, P. R. A., 1979. Chemical and thermal evolution of Archaean sialic crust, Southern West Greenland. Journ. Petrol. 20, 187-226.

Wetherhill, G. W.; Kouvo, O.; Tilton, G. R. \& Gast, P. W., 1962. Age measurements on rocks from the Finnish Precambrian. J. Geol. 70, 74-88.

White, A. J. R.; Jakes, P. \& Christie, D. M., 1971. Composition of greenstones and the hypothesis of sea-floor spreading in the Archaean. Geol. Soc. Aust. Sp. Publ. $3,47-56$.

Wilkman, W. W., 1921. Kivilajikartan selitys D4, Nurmes. Suomen geologinen yleiskartta 1:400 000. Geologinen tutkimuslaitos.

-, 1924. Suomen geologinen yleiskartta. Lehti Nurmes D4. Vuorilajikartan selitys. Geologinen komission.

Windley, B. F., 1973. Crustal development in the Precambrian Phil. Trans. Roy. Soc. London A 273, 321-341.

-, 1976. New tectonics models for the evolution of Archaean continents and oceans. In: B. F. Windley (editor),
The early history of the Earth. J. Wiley and Sons, New York N.Y. 105-112.

—, 1977. The evolving continents. J. Wiley and Sons, New York. N.Y. 385 p.

Windley, B. R. \& Bridgwater, D., 1971. The evolution of Archaean low-and high-grade terrains. Geol. Soc. Aust., Spec. Pub. 3, 33-46.

Windley, B. F. \& Smith, J. V., 1976. Archaean high-grade complexes and modern continental margins. Nature 260, 671-675.

Wyllie, P. J., 1971. Experimental limits for conditions for melting in the earth's crust and upper mantle. Am. Geophys. Union, Geophys. Monogr. 14, 279-302.

-, 1979. Magmas and volatile components. Am. Mineral. 64, 469-500.

Yoder, H. S. Jr., 1969. Calc alkaline andesites: experimental data bearing on the origin of the their assumed characteristics. In: Mac Birney A.R. (editor), Proc. Andesite Conf. Dep. Geol. Mineral. Res. Oreg. Bull. 65, 43-64.

Manuscript received, January 4, 1984. 